\title{
Design, Synthesis, Trypanocidal Activity, and Studies on Human Albumin Interaction of Novel $S$-Alkyl-1,2,4-triazoles
}

\author{
Tatiany N. Franklim, ${ }^{a, b}$ Leonardo Freire-de-Lima, ${ }^{b}$ Otávio A. Chaves, ${ }^{a}$ \\ Isabel F. LaRocque-de-Freitas, ${ }^{b}$ Joana D. da Silva-Trindade, ${ }^{a}$ José C. Netto-Ferreira, ${ }^{a, c}$ \\ Célio G. Freire-de-Lima, ${ }^{b}$ Debora Decoté-Ricardo, ${ }^{d}$ José O. Previato, ${ }^{b}$ \\ Lucia Mendonça-Previato ${ }^{b}$ and Marco E. F. de Lima ${ }^{\circledR *, a}$
}
anstituto de Química, Departamento de Química Orgânica, Universidade Federal Rural do Rio de Janeiro, BR 465, km 07, 23890-000 Seropédica-RJ, Brazil
${ }^{b}$ Instituto de Biofísica Carlos Chagas Filho, Universidade Federal do Rio de Janeiro, Cidade Universitária, Ilha do Fundão, 21941-902 Rio de Janeiro-RJ, Brazil

${ }^{c}$ Divisão de Metrologia Química, Instituto Nacional de Metrologia, Qualidade e Tecnologia (INMETRO), 25250-020 Duque de Caxias-RJ, Brazil

${ }^{d}$ Departamento de Microbiologia e Imunologia Veterinária, Instituto de Veterinária, Universidade Federal Rural do Rio de Janeiro, BR 465, km 07, 23890-000 Seropédica-RJ, Brazil

\begin{abstract}
Chagas disease is a neglected tropical disease caused by the hemoflagellated parasite Trypanosoma cruzi (Kinetoplastida). The only available drug to treat chagasic patients in Brazil, the nitroheterocycle benznidazole, is effective solely during the acute phase of the infection. There is accordingly a need to develop new therapeutic tools for the treatment of Chagas disease. This work reports the synthesis, trypanocidal evaluation and human serum albumin (HSA) interactions of a novel series of 1,2,4-triazoles. The new derivatives were synthesized via microwave irradiation in good yields. Most compounds showed toxic effects against T. cruzi with low toxicity to host cells. Three $S$-alkylated-triazoles showed the best activity profile against amastigotes, with half maximal inhibitory concentration $\left(\mathrm{IC}_{50}\right)$ values of $3.95 \pm 1.41,4.15 \pm 0.92$ and $3.61 \pm 0.65 \mu \mathrm{mol} \mathrm{L} \mathrm{L}^{-1}$, respectively. The interaction between HSA and 3-[(1E,3E)-4-(1,3-benzodioxol-5-yl)buta-1,3-dien1-yl]-5-(butylthio)-4-cyclohexyl-4,5-dihydro- $1 H$-1,2,4-triazole was investigated using multiple spectroscopic techniques and molecular docking, revealing that serum albumin is a potential endogenous carrier to this compound in the human bloodstream.
\end{abstract}

Keywords: Trypanosoma cruzi, piperine, molecular hybridization, 1,2,4-triazole-3-thioether, human serum albumin

\section{Introduction}

Chagas disease (CD), also known as American trypanosomiasis, is a chronic parasitic illness that, since its first description in 1909, had no effective chemotherapeutic treatment. ${ }^{1} \mathrm{CD}$ is caused by the hemoflagellate protozoan Trypanosoma cruzi (T. cruzi; Kinetoplastida, Trypanosomatidae) and is considered to be one of the human diseases most related to underdevelopment and poverty. These socioeconomic characteristics make critical the situation of millions of chagasic patients that face one of the

*e-mail: marco@ufrrj.br most neglected infections. Approximately 8 million people in 21 countries in Latin America are infected with T. cruzi. Of these patients, $20-30 \%$ will progress to the chronic phase of the infection, developing severe and irreversible cardiac, digestive, and neurological disorders. ${ }^{1}$ Furthermore, CD is the parasitic disease with the highest socioeconomic impact, being responsible for the loss of approximately US\$1.2 billion a year in productivity in Latin America. ${ }^{1,2}$ This infection is spreading to the United States and Europe, because of the conjunction of the increasing population exodus that occurs from poor countries towards these regions and the current climate changes that facilitate the adaptation of vector insects to different regions. ${ }^{3,4}$ 
The availability of drugs applicable to the treatment of $\mathrm{CD}$ is extremely limited in the acute phase. Only the nitroheterocycles benznidazole and nifurtimox are used as anti-chagasic drugs. These drugs have no efficacy in the chronic phase of the disease showing serious and deleterious side effects. ${ }^{5,6}$ Different molecular targets have been investigated, with the aim of developing new alternatives for the treatment of $\mathrm{CD}^{5-8}$ The structural diversity of natural products points out them as an attractive alternative for the development of new and more effective anti-chagasic drugs. ${ }^{9}$ Several classes of natural products and their derivatives have shown promising anti T. cruzi activity. Among them we can highlight quinones, ${ }^{10,11}$ terpenes, ${ }^{12}$ alkaloids, ${ }^{13}$ and diarylheptanoids. ${ }^{14}$

In planning the use of natural products as drugs or as raw materials for drug preparation, it is important to consider that most special metabolites of plant origin are ordinarily biosynthesized in small quantities; are difficult to isolate; and in most cases are not obtained from sustainable sources. Despite the great contribution of natural products in drug discovery, these limitations remain as a bottleneck for the use of products isolated from natural sources straight as precursors of new drugs. The natural amide piperine (1, Figure 1) is an exception among the special metabolites of plant origin. This natural amide, present in different species of the genus Piper, is most abundant in the fruits of Piper nigrum. ${ }^{15}$

Piperine was isolated for the first time about 200 years ago. Since then, it has attracted great interest due to its biological properties. ${ }^{16-19}$ The structural features of piperine (1) allow the planning of different synthetic manipulations. In addition, its occurrence in significant amounts in the fruits of Piper nigrum renders it a very promising starting material for the design of new bioactive molecules. Studies from our group aimed at tracing a structure-activity relationship (SAR) profile have demonstrated the toxic effects of piperine derivatives and analogues against different evolutive forms of L. amazonensis and T. cruzi. ${ }^{20-24}$

Azole derivatives were evaluated for CD experimental treatment and exhibited highly promising results. These azoles are commercially available drugs or molecules that were tested against other type of infections. ${ }^{25-28}$ The triazole ring has been applied in the development of new anticonvulsant, antidepressant, anti-inflammatory, analgesic, anticancer and anti-infective drugs and as a scaffold for the synthesis of other bioactive molecules. ${ }^{29,30}$ Recent studies have reported that 3-nitrotriazole-based piperazides derivatives showed activity against Trypanosoma brucei rhodesiense. ${ }^{31}$ Furthermore, a series of 1,2,3-triazole benznidazole analogs were synthesized and many of them exhibited activity comparable to that of the standard drug against trypomastigotes, with selective toxicity. ${ }^{2}$

Recently, we described the synthesis and trypanocidal evaluation of a new series of $N_{4}$-substituted 1,2,4-triazole3-thiones (e.g., 2) prepared from natural piperine (Figure 1). ${ }^{24}$ This heterocyclic core is an important framework for the development of bioactive molecules in several therapeutic fields. ${ }^{32}$ The new derivatives synthesized were planned through molecular hybridization ${ }^{33}$ as the main strategy for molecular modification. In the molecular planning of the new 1,2,4-triazole-3-thiones, the antifungal prothioconazole (Figure 1) was used as a starting point. Prothioconazole is a known inhibitor of the enzyme 14- $\alpha$-demethylase (CYP51), which plays an important role in $T$. cruzi cell membrane composition and structure due to its involvement in the biosynthesis of ergosterol..$^{34}$ The design of the new derivatives was based on the conjugation of the known trypanocidal effects of piperine to the ability of molecules possessing a triazole moiety to block the activity of CYP51, since nitrogen containing heterocycles play a pharmacophoric role in the structure of CYP51 inhibitors, by anchoring
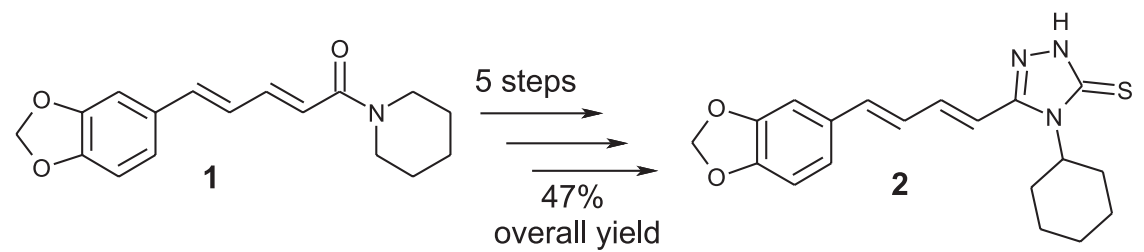

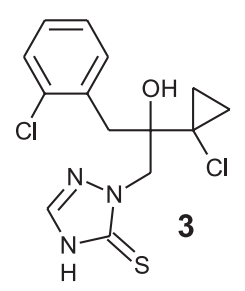

Figure 1. Chemical structure of the $N_{4}$-cyclohexyl-1,2,4-triazole-3-thione (2) prepared based on both piperine (1) and prothioconazole structures (3). 
to the porphyrin iron present at the active site of the enzyme. ${ }^{35}$ Among the triazole derivatives prepared, the $N_{4}$-cyclohexyl-1,2,4-triazole (2, Figure 1) was the one with the best trypanocidal profile with half maximal inhibitory concentration $\left(\mathrm{IC}_{50}\right)$ values of 18.30 and $8.87 \mu \mathrm{mol} \mathrm{L}^{-1}$ against the epimastigote and amastigote forms of $T$. cruzi, respectively. Additionally, these compounds exhibited low toxic effects against host cells (murine macrophages) with $85-95 \%$ cell viability at the highest tested drug concentration (median lethal dose $\left.\left(\mathrm{DL}_{50}\right)>14.08 \mu \mathrm{mol} \mathrm{L}{ }^{-1}\right){ }^{24}$

Herein a novel series of eight $1,2,4$-triazole derivatives was planned with the $N_{4}$-cyclohexyl-1,2,4-triazole moiety (2, Figure 1$)^{24}$ as a starting point; our goal was to optimize the antiparasitic profile of this substance. The trypanocidal activities of the novel derivatives prepared were assessed against the different evolutive forms of T. cruzi as well as their toxic effects against murine macrophages. The novel triazoles were prepared (Figure 2) with changes in both the substitution at the sulfur atom of the thioether function $(\mathbf{4 a - 4 d}),{ }^{36}$ and the butadienyl-benzodioxole moiety (5-8). The new derivatives and analogues were designed to obtain additional information on the SAR for this family of compounds.

Additionally, it was evaluated the interaction between one of the prepared triazoles with the best activity profile and human serum albumin (HSA), which is the most abundant human plasma protein. HSA has attracted great interest from the pharmaceutical industry because it can bind to a remarkable variety of endogenous and exogenous molecules, impacting their delivery and efficacy, and altering mainly their pharmacokinetic properties. ${ }^{37}$ Thus, binding affinity of any substance to HSA is one of the major factors that determine its pharmacokinetics (e.g., the time course of drug absorption, distribution, metabolism, and excretion). ${ }^{38}$ From a structural point of view, HSA is a non-glycosylated polypeptide (585 amino acid residues), with a heart-shaped structure composed of three structurally similar $\alpha$-helical domains (I-III). Each domain consists of two subdomains (A and B); subdomain IIA presents the Trp-214 residue, which is responsible for the intrinsic fluorescent properties of HSA. This intrinsic fluorescence is extensively used in ligand binding studies. ${ }^{39-41}$

\section{Experimental}

\section{General: organic synthesis}

Melting points were determined on a Büchi B-510 (Flawil, Switzerland) apparatus and were not corrected. The ${ }^{1} \mathrm{H}$ and ${ }^{13} \mathrm{C}$ nuclear magnetic resonance (NMR) spectra were recorded on a Bruker Ultrashield Plus Spectrometer (BrukerBioSpin GmbH, Rheinstetten, Germany) operating at $500 \mathrm{MHz}$ for ${ }^{1} \mathrm{H}$ and $125 \mathrm{MHz}$ for ${ }^{13} \mathrm{C} .{ }^{1} \mathrm{H}$ and ${ }^{13} \mathrm{C}$ NMR shifts $(\delta)$ are reported in parts per million (ppm) with respect to dimethyl sulfoxide (DMSO- $d_{6}$ ) and acetone (DMSO- $d_{6}, 2.50 \mathrm{ppm}$ for ${ }^{1} \mathrm{H}$ and $39.7 \mathrm{ppm}$ for ${ }^{13} \mathrm{C}$; acetone- $d_{6}, 2.05 \mathrm{ppm}$ for ${ }^{1} \mathrm{H}$ and $206.7 \mathrm{ppm}$ for ${ }^{13} \mathrm{C}$ ). Coupling constants $(J)$ were reported in hertz $(\mathrm{Hz})$. Signal multiplicity was assigned as singlet (s), doublet (d), doublet of doublets (dd), triplet (t), quartet (q), multiplet (m) and broad signal (bs). The low-resolution mass spectra (LRMS) were carried out on a Shimadzu GCMS-QP2010 Plus (Shimadzu Inc., Kyoto, Japan). Analytical conditions: column: VF-5MS, $30 \mathrm{~m} \times 0.25 \mathrm{~mm} \times 0.25 \mu \mathrm{m}$ (Varian Inc., Santa Clara, CA, USA); column temperature: $200{ }^{\circ} \mathrm{C}$ for $1 \mathrm{~min}$ and then increasing to $290{ }^{\circ} \mathrm{C}$ at a rate of $10{ }^{\circ} \mathrm{C} \mathrm{min}-1$ and holding for $40 \mathrm{~min}$; injector temperature: $270{ }^{\circ} \mathrm{C}$. High-resolution mass analysis was taken in the positive ion mode under electrospray inoziation (ESI) methods on a Bruker 9.4 T Apex-Qh (FT-ICR) (Bruker DaltonikGmbH Life Sciences, Bremen, Germany). All the reactions involving microwave instrumentation used the Discover SP system (CEM Inc., Matthews, NC, USA) and were performed in open vessel mode. Analytical thin-layer chromatography (TLC) was performed on pre-coated silica

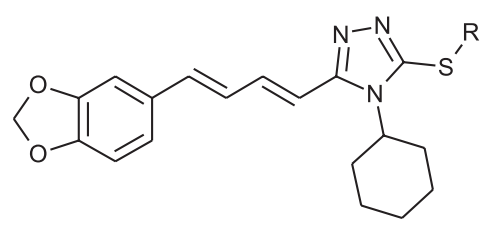

4a: $\mathrm{R}=-\mathrm{CH}_{3}$

4b: $\mathrm{R}=-\mathrm{CH}\left(\mathrm{CH}_{3}\right)_{2}$

4c: $\mathrm{R}=-\mathrm{CH}_{2}\left(\mathrm{CH}_{2}\right)_{2} \mathrm{CH}_{3}$

4d: $\mathrm{R}=-\mathrm{CH}_{2} \mathrm{C}_{6} \mathrm{H}_{5}$

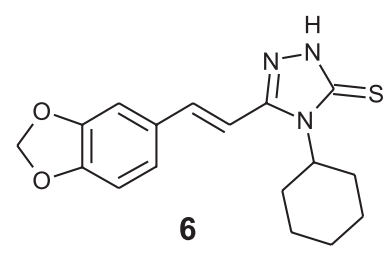

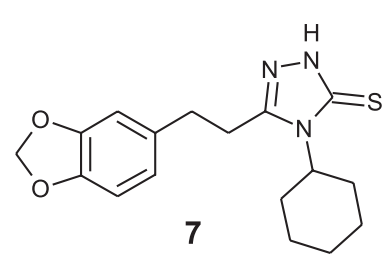

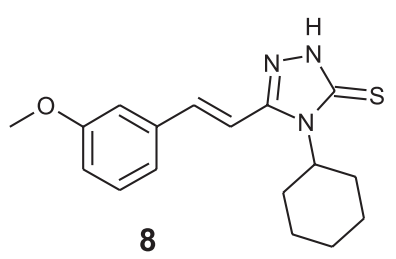

Figure 2. New series of 1,2,4-triazoles (4a-4d and 5) derived from natural piperine and lower chain analogues (6-8). 
gel plates $(0.25 \mathrm{~mm}$ layer thickness) in an appropriate solvent and the spots were visualized under UV light (254 or $356 \mathrm{~nm}$ ). Natural piperine used in this work was isolated from dry fruits of Piper nigrum as previously described. ${ }^{24}$

General procedure for the synthesis of new 1-cyclohexyl2-thioalkyl-1,2,4-triazole derivatives (4a-4d)

Triazole-thione 2 (100 mg, $0.28 \mathrm{mmol}$ ) was obtained according to previous work procedures..$^{24}$ Compound $\mathbf{2}$ was dissolved in $5 \mathrm{~mL}$ of ethanol in a $10 \mathrm{~mL}$ round bottom flask equipped with a magnetic stirring bar and a reflux apparatus. To this solution $\mathrm{KOH}(33.6 \mathrm{mg}, 0.60 \mathrm{mmol})$ dissolved in ethanol $(2 \mathrm{~mL})$ was added dropwise. The reaction mixture was then subjected to microwave irradiation (MW: $100 \mathrm{~W}$ ) for $5 \mathrm{~min}$ in open vessel mode. Thereafter, the appropriate stoichiometric amount of the corresponding alkyl halide (methyl, isopropyl, $n$-butyl and benzyl iodides) was added. The mixture was subjected to MW for $1 \mathrm{~h}$ and the evolution of the reaction was monitored by TLC. After elimination of solvent under reduced pressure, the solid formed was suspended in 5\% $\mathrm{KOH}$ aqueous solution and extracted three times with ethyl acetate. The organic solvent was evaporated under reduced pressure, giving the desired product in appropriate degree of purity after recrystallization from ethanol. All compounds were characterized by NMR as well as by low- and high-resolution mass spectra (HRMS). The yields, melting points and spectral data observed for each compound (4a-4d) are described below:

3-[(1E,3E)-4-(1,3-Benzodioxol-5-yl)buta-1,3-dien-1-yl]4-cyclohexyl-5-(methylthio)-4,5-dihydro-1 $H$-1,2,4-triazole (4a)

Brown amorphous solid, yield $73 \%$, m.p. $123-125^{\circ} \mathrm{C}$; ${ }^{1} \mathrm{H}$ NMR $\left(500 \mathrm{MHz}\right.$, acetone- $\left.d_{6}\right) \delta 7.42(\mathrm{dd}, 1 \mathrm{H}$, $J 14.81$ and $11.04 \mathrm{~Hz}), 6.99-7.12(\mathrm{~m}, 3 \mathrm{H}), 6.76-6.86$ $(\mathrm{m}, 3 \mathrm{H}), 6.03\left(\mathrm{~s}, 2 \mathrm{H},-\mathrm{O}-\mathrm{CH}_{2}-\mathrm{O}-\right), 4.24$ (bs, $1 \mathrm{H}$, $\left.-\mathrm{N}-\mathrm{CH}-\left(\mathrm{CH}_{2}-\mathrm{CH}_{2}\right)_{2}-\mathrm{CH}_{2}\right), 2.70\left(\mathrm{~s}, 3 \mathrm{H},-\mathrm{S}-\mathrm{CH}_{3}\right)$, 1.47-1.98 (m, $\left.10 \mathrm{H},-\mathrm{N}-\mathrm{CH}-\left(\mathrm{CH}_{2}-\mathrm{CH}_{2}\right)_{2}-\mathrm{CH}_{2}\right)$ (Figure $\mathrm{S} 1$, Supplementary Information (SI) section); ${ }^{13} \mathrm{C}$ NMR $\left(125 \mathrm{MHz}\right.$, acetone- $\left.d_{6}\right) \delta 153.28,149.85,148.38,147.95$, $135.61,135.39,131.61,126.60,122.12,114.92,108.33$, $105.37,101.40,55.88,31.29,25.69,24.77,15.05$ (Figure S2, SI section); LRMS $\mathrm{m} / \mathrm{z}, 369$; HRMS (ES) $m / z$, calcd. for $\mathrm{C}_{20} \mathrm{H}_{23} \mathrm{~N}_{3} \mathrm{O}_{2} \mathrm{~S}[\mathrm{M}+\mathrm{H}]^{+}: 370.15892$, found: 370.15837 (Figure $\mathrm{S} 3$, SI section).

3-[(1E,3E)-4-(1,3-Benzodioxol-5-yl)buta-1,3-dien-1-yl]4-cyclohexyl-5-(isopropylthio)-4,5-dihydro-1 $H-1,2,4$-triazole (4b)

Yellow amorphous solid, yield $65 \%$, m.p. $134-136{ }^{\circ} \mathrm{C}$;
${ }^{1} \mathrm{H}$ NMR $\left(500 \mathrm{MHz}\right.$, acetone- $\left.d_{6}\right) \delta 7.45(\mathrm{dd}, 1 \mathrm{H}, J 15.13$ and $10.72 \mathrm{~Hz}), 7.01-7.14(\mathrm{~m}, 3 \mathrm{H}), 6.81-6.87(\mathrm{~m}, 3 \mathrm{H}), 6.04(\mathrm{~s}, 2 \mathrm{H}$, $-\mathrm{O}-\mathrm{CH}_{2}-\mathrm{O}-$ ), 4.36 (bs, $1 \mathrm{H},-\mathrm{N}-\mathrm{CH}-\left(\mathrm{CH}_{2}-\mathrm{CH}_{2}\right)_{2}-\mathrm{CH}_{2}$ ), $3.80(\mathrm{~m}, 1 \mathrm{H}), 1.39\left(\mathrm{~d}, \mathrm{~J} 5 \mathrm{~Hz}, 6 \mathrm{H},-\mathrm{S}-\mathrm{CH}-\left(\mathrm{CH}_{2}\right)_{2}\right), 1.39-1.50$ (m, $10 \mathrm{H},-\mathrm{N}-\mathrm{CH}-\left(\mathrm{CH}_{2}-\mathrm{CH}_{2}\right)_{2}-\mathrm{CH}_{2}$ ) (Figure $\mathrm{S} 4$, SI section); ${ }^{13} \mathrm{C}$ NMR $\left(125 \mathrm{MHz}\right.$, acetone- $\left.d_{6}\right) \delta 152.89,148.55,148.38$, 147.96, 135.71, 135.46, 131.58, 126.58, 122.20, 115.12, 108.36, 105.29, 101.43, 55.97, 39.48, 31.48, 25.75, 24.73, 22.75 (Figure S5, SI section); LRMS m/z, 397; HRMS (ES) $m / z$, calcd. for $\mathrm{C}_{20} \mathrm{H}_{23} \mathrm{~N}_{3} \mathrm{O}_{2} \mathrm{~S}[\mathrm{M}+\mathrm{H}]^{+}: 398.19022$; found: 398.18967 (Figure S6, SI section).

3-[(1E,3E)-4-(1,3-Benzodioxol-5-yl)buta-1,3-dien-1-yl]5-(butylthio)-4-cyclohexyl-4,5-dihydro-1 $\mathrm{H}$-1,2,4-triazole (4c)

Yellow amorphous solid, yield 65\%, m.p. $138-140{ }^{\circ} \mathrm{C}$; ${ }^{1} \mathrm{H} \mathrm{NMR}\left(500 \mathrm{MHz}\right.$, acetone- $\left.d_{6}\right) \delta 7.43(\mathrm{dd}, 1 \mathrm{H}, J 14.98$ and $10.88 \mathrm{~Hz}), 7.00-7.13(\mathrm{~m}, 3 \mathrm{H}), 6.78-6.87(\mathrm{~m}, 3 \mathrm{H}), 6.05(\mathrm{~s}, 2 \mathrm{H}$, -O-CH $-\mathrm{O}-$ ), 4.29 (bs, $\left.1 \mathrm{H},-\mathrm{N}-\mathrm{CH}-\left(\mathrm{CH}_{2}-\mathrm{CH}_{2}\right)_{2}-\mathrm{CH}_{2}\right)$, 3.24 (t, $\left.2 \mathrm{H}, J 8.20 \mathrm{~Hz}, \mathrm{~S}-\mathrm{CH}_{2}\right), 1.31-1.94(\mathrm{~m}, 14 \mathrm{H}), 0.95$ (t, 3H, J $7.41 \mathrm{~Hz},-\mathrm{S}-\mathrm{CH}-\left(\mathrm{CH}_{2}\right)_{2}-\mathrm{CH}_{3}$ ) (Figure S7, SI section); ${ }^{13} \mathrm{C}$ NMR (125 MHz, acetone- $\left.d_{6}\right) \delta 153.01,148.99$, $148.39,147.95,135.51,135.14,131.61,126.61,122.15$, $115.15,108.34,105.28,101.43,55.83,33.03,31.51$, $31.38,25.74,24.76,21.53,13.00$ (Figure $\mathrm{S} 8$, SI section); LRMS $m / z, 411$; HRMS (ES) $m / z$, calcd. for $\mathrm{C}_{23} \mathrm{H}_{29} \mathrm{~N}_{3} \mathrm{O}_{2} \mathrm{~S}$ $[\mathrm{M}+\mathrm{H}]^{+}:$412.20587, found: 412.20532 (Figure S9, SI section).

3-[(1E,3E)-4-(1,3-Benzodioxol-5-yl)buta-1,3-dien1-yl]-5-(benzylthio)-4-cyclohexyl-4,5-dihydro1H-1,2,4-triazole(4d)

Yellow amorphous solid, yield 62\%, m.p. 140$142{ }^{\circ} \mathrm{C}$; ${ }^{1} \mathrm{H}$ NMR $\left(500 \mathrm{MHz}\right.$, acetone- $\left.d_{6}\right) \delta$ 7.28-7.41 $(\mathrm{m}, 6 \mathrm{H}), 6.84-7.13(\mathrm{~m}, 5 \mathrm{H}), 6.76(\mathrm{~d}, 1 \mathrm{H}, J 15.45 \mathrm{~Hz})$, $6.05\left(\mathrm{~s}, 2 \mathrm{H},-\mathrm{O}-\mathrm{CH}_{2}-\mathrm{O}-\right), 4.44(\mathrm{~s}, 2 \mathrm{H}), 4.20$ (bs, $\left.1 \mathrm{H},-\mathrm{N}-\mathrm{CH}-\left(\mathrm{CH}_{2}-\mathrm{CH}_{2}\right)_{2}-\mathrm{CH}_{2}\right), 1.22-1.85(\mathrm{~m}, 10 \mathrm{H})$ (Figure S10, SI section); ${ }^{13} \mathrm{C}$ NMR $\left(125 \mathrm{MHz}\right.$, acetone- $d_{6}$ ) $\delta$ 153.04, 148.51, 148.40, 147.97, 137.68, 135.65, 135.31, $131.58,129.04,128.53,127.46,126.56,122.18,115.12$, $108.34,105.28,101.43,55.94,38.36,31.31,25.72,24.69$ (Figure S11, SI section); LRMS $m / z$, 445; HRMS (ES) $m / z$, calcd. for $\mathrm{C}_{26} \mathrm{H}_{27} \mathrm{~N}_{3} \mathrm{O}_{2} \mathrm{~S}[\mathrm{M}+\mathrm{H}]^{+}: 446.19022$, found: 446.18967 (Figure S12, SI section).

General procedure for the synthesis of hydrazides 11,14 , 16 and 19

The corresponding carboxylic acid $(1.0 \mathrm{mmol})$ and oxalyl chloride $(10 \mathrm{mmol})$ were added to a $10 \mathrm{~mL}$ round bottom flask equipped with a magnetic stirring bar. A rubber septum was used and the reaction was kept under 
a dry $\mathrm{N}_{2}$ atmosphere. The resulting solution was subjected to stirring at room temperature for about $0.5 \mathrm{~h}$ and the evolution of the reaction was accompanied by TLC (indirectly by the reaction of an aliquot with methanol leading to the spontaneous formation of the corresponding methyl ester). After the removal of oxalyl chloride excess the residue was dissolved in dry dichloromethane $(3.0 \mathrm{~mL})$. The resulting solution was added dropwise to an ice-cooled mixture of hydrazine monohydrate $(15 \mathrm{mmol})$ and dichloromethane $(5 \mathrm{~mL})$ placed in a $25 \mathrm{~mL}$ round bottom flask equipped with a stirring bar. A rubber septum was used and the reaction was kept under a dry $\mathrm{N}_{2}$ atmosphere. After reaching room temperature (about $30 \mathrm{~min}$ ), the solvent was removed under reduced pressure. The product precipitated after the addition of ice water to the previously obtained residue and was then filtered, leading to the formation of the desired hydrazides as a solid material (72-91\% yield). All the hydrazides obtained, e.g., 11, 14, 16 and 19, were characterized by LRMS, ${ }^{1} \mathrm{H}$ and ${ }^{13} \mathrm{C}$ NMR.

\section{5-(1,3-Benzodioxol-5-yl)pentanohydrazide (11)}

Yellow amorphous solid, yield $72 \%$; ${ }^{1} \mathrm{H}$ NMR (500 MHz, acetone- $\left.d_{6}\right) \delta 6.74-6.76(\mathrm{~m}, 2 \mathrm{H}), 6.67-6.69(\mathrm{~m}$, $1 \mathrm{H}), 5.95\left(\mathrm{~s}, 2 \mathrm{H},-\mathrm{O}-\mathrm{CH}_{2}-\mathrm{O}-\right)$, 2.56-2.59 (t, 2H), 2.06$2.07(\mathrm{t}, 2 \mathrm{H}), 1.63(\mathrm{~s}, 4 \mathrm{H}) ;{ }^{13} \mathrm{C}$ NMR $\left(125 \mathrm{MHz}\right.$, acetone- $\left.d_{6}\right)$ $\delta 165.17,147.62,136.39,121.06,108.67,107.84,100.73$, 35.06, 33.21, 31.99, 31.33; MS m/z: 236.

\section{(2E)-3-(1,3-Benzodioxol-5-yl)acrylohydrazide (14)}

Yellow amorphous solid, yield $80 \%$; ${ }^{1} \mathrm{H}$ NMR $\left(500 \mathrm{MHz}\right.$, acetone- $\left.d_{6}\right) \delta$ 9.2-9.6 $(\mathrm{d}, 1 \mathrm{H}), 7.6(\mathrm{~d}, 1 \mathrm{H})$, 7.4-7.5 (d, 1H), 7.1-7.2 (m, 1H), $6.9(\mathrm{~d}, 1 \mathrm{H}), 6.1(\mathrm{~s}, 2 \mathrm{H}$, -O- $\left.\mathrm{CH}_{2}-\mathrm{O}-\right)$; ${ }^{13} \mathrm{C}$ NMR $\left(125 \mathrm{MHz}\right.$, acetone- $\left.d_{6}\right) \delta 165.21$, $148.85,148.38,141.5,129.9,123.9,115.9,108.4,106.4$, 101.7; MS m/z: 206.

\section{3-(1,3-Benzodioxol-5-yl)propanohydrazide (16)}

Yellow amorphous solid, yield 77\%; ${ }^{1} \mathrm{H}$ NMR $\left(500 \mathrm{MHz}\right.$, DMSO- $\left.d_{6}\right) \delta$ 6.7-6.84 (m, 3H), 5.97 (s, 2H, $\left.-\mathrm{O}-\mathrm{CH}_{2}-\mathrm{O}-\right), 2.77$ (t, $\left.J 7.7 \mathrm{~Hz}, 2 \mathrm{H}\right), 2.41(\mathrm{t}, J 7.7 \mathrm{~Hz}$, $2 \mathrm{H}) ;{ }^{13} \mathrm{C}$ NMR (125 MHz, DMSO- $\left.d_{6}\right) \delta 170.80,147.58$, 145.86, 135.23, 121.55, 109.27, 108.54, 101.08, 35.64, 30.84; MS m/z: 208.

\section{(2E)-3-(3-Methoxyphenyl)acrylohydrazide (19)}

Yellow amorphous solid, yield 91\%; ${ }^{\mathrm{H}} \mathrm{NMR}(500 \mathrm{MHz}$, acetone- $\left.d_{6}\right) \delta 7.56-7.68(\mathrm{~m}, 2 \mathrm{H}), 6.87-7.36(\mathrm{~m}, 4 \mathrm{H}), 3.84(\mathrm{~s}$, $\left.3 \mathrm{H},-\mathrm{O}-\mathrm{CH}_{3}\right) ;{ }^{13} \mathrm{C}$ NMR $\left(125 \mathrm{MHz}\right.$, acetone- $\left.d_{6}\right) \delta 166.01$, $160.16,141.7,140.31,136.89,129.88,120.22,115.41$, 113.10, 54.71; MS m/z: 192.
General procedure for the synthesis of the new 1,2,4-triazole3-thiones 5, 6, 7 and 8

Cyclohexylisothiocyanate $(0.6 \mathrm{mmol})$ was added to a suspension of the corresponding hydrazide $(0.5 \mathrm{mmol})$ in ethanol $(5 \mathrm{~mL})$. The mixture was placed in a $10 \mathrm{~mL}$ round bottom flask equipped with a magnetic stirring bar and a reflux apparatus. Then the reaction was subjected to microwave irradiation (MW: $100 \mathrm{~W}$ ) for $0.5 \mathrm{~h}$ in open vessel mode. The evolution of the reaction was monitored by TLC. After total consumption of the starting hydrazide, all the volatile compounds were removed under reduced pressure. It was added an aqueous solution of $\mathrm{NaOH}(1 \mathrm{mmol}$ in $2 \mathrm{~mL}$ of water) to the solid residue. This mixture was then subjected again to additional $0.5 \mathrm{~h}$ of $\mathrm{MW}(100 \mathrm{~W})$ in open vessel mode. The evolution of the reaction was monitored by TLC until its completion. Then, the mixture was acidified until $\mathrm{pH} 3$ with a $10 \% \mathrm{~m} / \mathrm{v} \mathrm{HCl}$ aqueous solution. The solid obtained was filtered and washed twice with ice water $(5 \mathrm{~mL})$. After recrystallization from ethanol the corresponding cyclohexyltriazoles 5, 6, 7, and $\mathbf{8}$ were obtained as yellow amorphous solids and characterized by ${ }^{1} \mathrm{H}$ and ${ }^{13} \mathrm{C}$ NMR and HRMS.

5-[4-(1,3-Benzodioxol-5-yl)butyl]-4-cyclohexyl-2,4-dihydro$3 \mathrm{H}-1,2,4$-triazole-3-thione (5)

Yellow amorphous solid, yield $72 \%$, m.p. 152-154 ${ }^{\circ} \mathrm{C}$; ${ }^{1} \mathrm{H}$ NMR $\left(500 \mathrm{MHz}\right.$, acetone- $\left.d_{6}\right) \delta 6.88$ $6.75(\mathrm{~m}, 3 \mathrm{H}), 5.95\left(\mathrm{~s}, 2 \mathrm{H},-\mathrm{O}-\mathrm{CH}_{2}-\mathrm{O}-\right), 4.52$ (bs, $\left.1 \mathrm{H},-\mathrm{NH}-\mathrm{CH}-\left(\mathrm{CH}_{2}-\mathrm{CH}_{2}\right)_{2}-\mathrm{CH}_{2}\right), 2,10-2.84(\mathrm{~m}, 6 \mathrm{H})$, $1.15-2.00(\mathrm{~m}, 12 \mathrm{H})$ (Figure S13, SI section); ${ }^{13} \mathrm{C}$ NMR $\left(125 \mathrm{MHz}\right.$, acetone- $\left.d_{6}\right) \delta 174.25,152.28,147.63,145.70$, 136.04, 121.13, 108.67, 107.89, 100.79, 56.22, 34.98, 34.82, 31.12, 30.78, 25.81, 24.88 (Figure S14, SI section); LRMS $m / z, 359$; HRMS (ES) $m / z$, calcd. for $\mathrm{C}_{19} \mathrm{H}_{25} \mathrm{~N}_{3} \mathrm{O}_{2} \mathrm{~S}$ $[\mathrm{M}+\mathrm{H}]^{+}:$360.17457, found 360.17402 (Figure S15, SI section).

5-[(E)-2-(1,3-Benzodioxol-5-yl)vinyl]-4-cyclohexyl2,4-dihydro-3H-1,2,4-triazole-3-thione (6)

Yellow amorphous solid, yield 70\%, m.p. 203-205 ${ }^{\circ} \mathrm{C}$; ${ }^{1} \mathrm{H}$ NMR $\left(500 \mathrm{MHz}\right.$, acetone- $\left.d_{6}\right) \delta 7.45(\mathrm{~d}, 1 \mathrm{H}$, $J 15.76 \mathrm{~Hz}), 7.36(\mathrm{~s}, 1 \mathrm{H}), 7.15(\mathrm{~d}, 1 \mathrm{H}, J 7.88 \mathrm{~Hz}), 7.08$ (d, 1H, J 16.08 Hz), 6.91 (d, 1H, J 8.20 Hz), 6.09 (s, 2H, $-\mathrm{O}-\mathrm{CH}_{2}-\mathrm{O}-$ ), 4.89 (bs, $\left.1 \mathrm{H},-\mathrm{NH}-\mathrm{CH}-\left(\mathrm{CH}_{2}-\mathrm{CH}_{2}\right)_{2}-\mathrm{CH}_{2}\right)$, 1.30-1.93 (m, $\left.10 \mathrm{H},-\mathrm{N}-\mathrm{CH}-\left(\mathrm{CH}_{2}-\mathrm{CH}_{2}\right)_{2}-\mathrm{CH}_{2}\right)$ (Figure S16, SI section); ${ }^{13} \mathrm{C}$ NMR (125 MHz, acetone- $d_{6}$ ) $\delta$ 167.87, 149.86, 148.95, 148.51, 136.47, 129.98, 123.60, 109.84, 108.33, 105.90, 101.66, 55.72, 30.10, 25.88, 24.74 (Figure S17, SI section); LRMS $m / z, 329$; HRMS (ESI-positive mode) $m / z$, calcd. for $\mathrm{C}_{17} \mathrm{H}_{19} \mathrm{~N}_{3} \mathrm{O}_{2} \mathrm{~S}$ 
$[\mathrm{M}+\mathrm{H}]^{+}:$330.12762, found 330.12707 (Figure S18, SI section).

5-[2-(1,3-Benzodioxol-5-yl)ethyl]-4-cyclohexyl-2,4-dihydro$3 H-1,2,4$-triazole-3-thione (7)

Yellow amorphous solid, yield $75 \%$, m.p. $160-162{ }^{\circ} \mathrm{C}$; ${ }^{1} \mathrm{H}$ NMR $\left(500 \mathrm{MHz}\right.$, acetone- $\left.d_{6}\right) \delta 6.74-6.81(\mathrm{~m}, 2 \mathrm{H})$, $6.56(\mathrm{~s}, 1 \mathrm{H}), 5.96$ (s, 2H, $\left.-\mathrm{O}-\mathrm{CH}_{2}-\mathrm{O}-\right), 4.14$ (bs, $1 \mathrm{H}$, $\left.-\mathrm{NH}-\mathrm{CH}-\left(\mathrm{CH}_{2}-\mathrm{CH}_{2}\right)_{2}-\mathrm{CH}_{2}\right), 2.84(\mathrm{t}, 2 \mathrm{H}, J 7.6 \mathrm{~Hz})$, $2.59(\mathrm{t}, 2 \mathrm{H}, J 7.6 \mathrm{~Hz}), 1.16-1.35\left(\mathrm{~m}, 10 \mathrm{H},-\mathrm{N}-\mathrm{CH}-\mathrm{CH}_{2}-\right.$ $\left.\mathrm{CH}_{2}\right)_{2}-\mathrm{CH}_{2}$ ) (Figure $\mathrm{S} 19$, SI section); ${ }^{13} \mathrm{C}$ NMR $(125 \mathrm{MHz}$, acetone- $\left.d_{6}\right) \delta 173.00,145.94,144.32,134.95,121.13$, 108.72, 107.94, 100.84, 52.14, 35.35, 32.64, 30.37, 25.45, 24.81 (Figure S20, SI section); LRMS $\mathrm{m} / \mathrm{z}, 331$; HRMS (ESI-negative mode) $\mathrm{m} / z$, calcd. for $\mathrm{C}_{17} \mathrm{H}_{20} \mathrm{~N}_{3} \mathrm{O}_{2} \mathrm{~S}[\mathrm{M}-\mathrm{H}]^{-}$: 330.12762 , found 330.12850 (Figure S21, SI section).

4-Cyclohexyl-5-[(E)-2-(3-methoxyphenyl)vinyl]-2,4-dihydro$3 \mathrm{H}-1,2,4$-triazole-3-thione (8)

White amorphous solid, yield $81 \%$, m.p. $202-204{ }^{\circ} \mathrm{C}$; ${ }^{1} \mathrm{H}$ NMR (500 MHz, DMSO- $\left.d_{6}\right) \delta$ 7.28-7.40 (m, 4H), 7.15 (d, 1H, J $15.76 \mathrm{~Hz}), 6.95(\mathrm{~d}, 1 \mathrm{H}, J 7.25 \mathrm{~Hz}), 4.72$ (bs, $\left.1 \mathrm{H},-\mathrm{NH}-\mathrm{CH}-\left(\mathrm{CH}_{2}-\mathrm{CH}_{2}\right)_{2}-\mathrm{CH}_{2}\right), 3.81\left(\mathrm{~s}, 3 \mathrm{H},-\mathrm{O}-\mathrm{CH}_{3}\right)$, 1.13-1.86 (m, 10H) (Figure S22, SI section); ${ }^{13} \mathrm{C}$ NMR $\left(125 \mathrm{MHz}, \mathrm{DMSO}-d_{6}\right) \delta 166.96,160.06,149.59,137.28$, $130.33,120.24,114.99,113.53,55.65,55.33,30.51,26.08$, 25.05 (Figure S23, SI section); LRMS $\mathrm{m} / \mathrm{z}, 315$; HRMS (ESI-positive mode) $\mathrm{m} / z$, calcd. for $\mathrm{C}_{17} \mathrm{H}_{21} \mathrm{~N}_{3} \mathrm{OS}[\mathrm{M}+\mathrm{H}]^{+}$: 316.14835, found 316.14781 (Figure S24, SI section).

\section{Ethical statement}

All animal procedures were approved by the animalcare ethics committee of the Centro de Ciências da Saúde, UFRJ (License No. DAHEICB 055) and were performed under the guidelines from SBCAL (Brazilian Society of Science in Laboratory Animals) and strictly followed the Brazilian Law for Procedures for the Scientific Use of Animals (11.794/2008).

\section{Biological assays}

\section{Parasites}

Trypanosoma cruzi (Y-strain) was provided by the Trypanosomatid Collection of the Oswaldo Cruz Institute, Fiocruz, Rio de Janeiro, Brazil. Parasites were grown at $28{ }^{\circ} \mathrm{C}$ for 7 days in brain-heart infusion medium (BHI, BD Bacto, Sparks, Maryland, USA) supplemented with $10 \mu \mathrm{g} \mathrm{L}^{-1}$ hemin (Sigma, MO, USA), $20 \mu \mathrm{g} \mathrm{L}^{-1}$ folic acid (Sigma, St. Louis, MO, USA), and 10\% (v/v) fetal bovine serum (FBS; Gibco, Dublin, Ireland). Parasite growth was monitored by cell counting in a Neubauer chamber. ${ }^{42}$ Tissue culture-derived trypomastigotes (TCT) were obtained after infection of confluent monolayers of Vero cells (kidney epithelial cells extracted from African green monkeys) with blood trypomastigotes (Y strain) to establish the intracellular cycle and maintained in Roswell Park Memorial Institute (RPMI) 1640 medium containing 10\% (v/v) FBS under an atmosphere of $5 \% \mathrm{CO}_{2}$ at $37{ }^{\circ} \mathrm{C}$. The TCT forms were collected from the culture supernatants, washed with medium, and then used to infect murine peritoneal macrophages (MP-M $\phi$ ) (see below).

\section{Anti-epimastigote effect}

The toxic effect of the drugs on epimastigote forms was evaluated as previously described. ${ }^{20-22,24}$ The drugs were stored as $10 \mathrm{mg} \mathrm{mL}^{-1}$ stock solution in DMSO and used in serial dilution (1:2) in BHI-FBS medium. Drug-free control medium contained comparable final concentration of DMSO $(0.25 \%)$. Epimastigotes $\left(2.0 \times 10^{5}\right.$ cells $)$ were incubated in BHI-FBS medium with or without the drug to a final volume of $2.0 \mathrm{~mL}$ in 24 -well plates. After 7 days of treatment, the toxic effect of the drugs was quantified by the direct count of the live epimastigotes in a Neubauer chamber.

\section{Cytotoxicity to macrophages}

The assessment of the toxic effects of each compound was carried out as previously described. ${ }^{20-22,24}$ MP-M $\phi$ adhered to 24-well plates were treated with the compounds at the indicated concentrations $\left(1-20 \mu \mathrm{g} \mathrm{mL}^{-1}\right)$ for $72 \mathrm{~h}$ at $37^{\circ} \mathrm{C}$ in $5 \% \mathrm{CO}_{2}$. The cells were then washed and incubated with the vital dye trypan blue in a final concentration $0.3 \%$. The number of viable cells was scored by the count of 200 cells where plasma membrane permeability was evaluated. ${ }^{24}$

\section{Anti-amastigote effect}

Assays of anti-amastigote activity were performed in MP-M $\phi$. Cells were seeded at a density of $2.0 \times 10^{5}$ cells per well in 24-well microplates with rounded coverslips on the bottom. After infection in a parasite-to-cell ratio of 10:1 for $24 \mathrm{~h}$ at $37^{\circ} \mathrm{C}$, extracellular parasites were removed by six washes with phosphate buffer solution (PBS), $\mathrm{pH}$ 7.2, and fresh medium containing or not increasing concentrations (1.0-20 $\left.\mu \mathrm{g} \mathrm{mL}^{-1}\right)$ of each compound was added. Seventy-two hours later, the coverslips were fixed with methanol (Merck, Darmstadt, Germany), stained with Giemsa (Sigma, St. Louis, MO, USA), and the number of amastigotes per 100 cells was calculated by use of light microscopy. Anti-amastigote activity was determined by the counting of 200 cells in triplicate, where the percentage 
of infected cells was analyzed, as well as the number of amastigotes per MP-M $\phi .^{24}$

\section{Statistical analysis}

The $50 \%$ inhibitory concentrations $\left(\mathrm{IC}_{50}\right)$ values shown in Table 1 represent the mean of three experiments carried out in triplicate. $\mathrm{The}^{\mathrm{IC}_{50}}$ of all compounds were determined by linear regression analysis using the program IGOR Pro 2.03. ${ }^{43}$

Table 1. Trypanocidal activity of new cyclohexyl-1,2,4-triazole3-thioethers 4a-4d and cyclohexyl-1,2,4-triazole-3-thiones 2, 5-8 against replicative forms of $T$. cruzi (Y strain)

\begin{tabular}{lcc}
\hline \multirow{2}{*}{ Triazole } & \multicolumn{2}{c}{$\mathrm{IC}_{50} /\left(\mu \mathrm{mol} \mathrm{L}^{-1}\right)$} \\
\cline { 2 - 3 } & \multicolumn{1}{c}{ Epimastigote } & Amastigote \\
\hline $\mathbf{2}^{\mathrm{a}}$ & $18.30 \pm 5.21$ & $8.87 \pm 1.16$ \\
$\mathbf{4 a}$ & $7.52 \pm 1.65$ & $9.51 \pm 2.33$ \\
$\mathbf{4 b}$ & $3.52 \pm 0.91$ & $3.95 \pm 1.41$ \\
$\mathbf{4 c}$ & $3.18 \pm 0.78$ & $4.15 \pm 0.92$ \\
$\mathbf{4 d}$ & $3.36 \pm 0.55$ & $3.61 \pm 0.65$ \\
$\mathbf{5}$ & $12.46 \pm 3.01$ & $12.81 \pm 1.88$ \\
$\mathbf{6}$ & $11.83 \pm 2.82$ & $13.35 \pm 3.82$ \\
$\mathbf{7}$ & $7.93 \pm 1.14$ & $9.41 \pm 3.26$ \\
$\mathbf{8}$ & $>79$ & $\mathrm{nt}^{\mathrm{b}}$ \\
Benznidazole $^{\mathrm{c}}$ & $2.20 \pm 0.16$ & $2.50 \pm 0.21$ \\
\hline
\end{tabular}

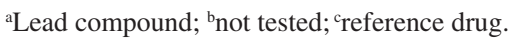

Procedure for the studies of the interaction between HSA and 4c: spectroscopic measurements

Commercially available HSA, PBS buffer $(\mathrm{pH}=7.4)$, warfarin, ibuprofen and digitoxin were obtained from Sigma-Aldrich Chemical Company (St. Louis, MO, USA). Water used in all experiments was Millipore grade. Acetonitrile (spectroscopic grade) was obtained from Tedia (Fairfield, OH, USA).

UV-Vis and steady state fluorescence spectra were measured on a Jasco J-815 fluorimeter (Easton, MD, USA) using a quartz cell $(1.00 \mathrm{~cm}$ optical path) and employing a thermostatic cuvette holder Jasco PFD-425S15F. The circular dichroism spectra were measured in a spectropolarimeter Jasco J-815 (Easton, MD, USA), employing the same thermostatic cuvette holder as described above. All spectra were recorded with appropriate background corrections. Due the fact that $4 \mathbf{c}$ shows absorption higher than 0.10 a.u. at 280 and $340 \mathrm{~nm}$ (Figure S25, SI section), the correction for the inner filter effect was made, according to the equation $1:{ }^{44}$

$\mathrm{F}_{\text {cor }}=\mathrm{F}_{\mathrm{obs}} 10^{\left[\left(\mathrm{A}_{\mathrm{ex}}+\mathrm{A}_{\mathrm{em}}\right) / 2\right]}$ where, $\mathrm{F}_{\text {cor }}$ and $\mathrm{F}_{\mathrm{obs}}$ are the corrected and observed fluorescence intensity values, respectively, while $\mathrm{A}_{\mathrm{ex}}$ and $\mathrm{A}_{\mathrm{em}}$ represent the absorbance value at the excitation $(\lambda=280 \mathrm{~nm}$ : $\varepsilon=23,905 \mathrm{~cm}^{-1} \mathrm{M}^{-1}$, in PBS) and emission wavelengths ( $\lambda=340 \mathrm{~nm}: \varepsilon=29,744 \mathrm{~cm}^{-1} \mathrm{M}^{-1}$, in PBS).

The UV-Vis absorption spectrum for $4 \mathbf{c}\left(1.32 \times 10^{-5} \mathrm{M}\right.$, in PBS) was measured in the $200-600 \mathrm{~nm}$ range at room temperature. The steady state fluorescence measurements were carried out in the $290-450 \mathrm{~nm}$ range $\left(\lambda_{\text {exc }}=280 \mathrm{~nm}\right)$ at $296,303,310$, and $317 \mathrm{~K}$ and using $3.0 \mathrm{~mL}$ of an HSA solution $\left(1.00 \times 10^{-5} \mathrm{M}\right.$, in PBS). The addition of $4 \mathbf{c}$ to the HSA solution was done manually by using a micro syringe, achieving final concentrations of $0.17 ; 0.33 ; 0.50 ; 0.66$; $0.83 ; 0.99 ; 1.15$; and $1.32 \times 10^{-5} \mathrm{M}$.

In order to obtain quantitative information on the binding ability of the interaction between HSA and $\mathbf{4 c}$, Stern-Volmer (equation 2), double logarithmic (equation 3), modified Stern-Volmer (equation 4), van't Hoff (equation 5) and Gibbs' free energy (equation 6) analyses were applied: ${ }^{45,46}$

$\frac{\mathrm{F}_{0}}{\mathrm{~F}}=1+\mathrm{k}_{\mathrm{q}} \tau_{0}[\mathrm{Q}]=1+\mathrm{K}_{\mathrm{SV}}[\mathrm{Q}]$

$\log \left(\frac{\mathrm{F}_{0}-\mathrm{F}}{\mathrm{F}}\right)=\log \mathrm{K}_{\mathrm{b}}+\mathrm{n} \log [\mathrm{Q}]$

$\frac{\mathrm{F}_{0}}{\mathrm{~F}_{0}-\mathrm{F}}=\frac{1}{f[\mathrm{Q}] \mathrm{K}_{\mathrm{a}}}+\frac{1}{f}$

$\ln \mathrm{K}_{\mathrm{a}}=-\frac{\Delta \mathrm{H}^{0}}{\mathrm{RT}}+\frac{\Delta \mathrm{S}^{0}}{\mathrm{R}}$

$\Delta \mathrm{G}^{0}=\Delta \mathrm{H}^{0}-\mathrm{T} \Delta \mathrm{S}^{0}$

where $F_{0}$ and $F$ are the steady state fluorescence intensities of HSA in the absence and in the presence of $\mathbf{4 c}$, respectively. [Q], $\mathrm{K}_{\mathrm{SV}}$ and $\mathrm{k}_{\mathrm{q}}$ are the ligand concentration, Stern-Volmer quenching constant and bimolecular quenching rate constant, respectively. $\tau_{0}$ is the experimental fluorescence lifetime of HSA in the absence of $4 \mathbf{c}(5.46 \pm 0.08) \times 10^{-9} \mathrm{~s} . \mathrm{K}_{\mathrm{b}}$ and $\mathrm{n}$ are the binding constant and the number of binding sites, respectively. $K_{a}$ and $f$ are the modified Stern-Volmer binding and fraction of the initial fluorescence intensity corresponding to the fluorophore that is accessible by the quencher ( $f$ ca. 1.00), respectively. $\Delta \mathrm{H}^{\circ}, \Delta \mathrm{S}^{\circ}$ and $\Delta \mathrm{G}^{\circ}$ are the enthalpy, entropy and Gibbs' free energy change, respectively. $T$ and $R$ are the temperature $(296,303,310$ and $317 \mathrm{~K})$ and gas constant $\left(8.3145 \mathrm{~J} \mathrm{~mol}^{-1} \mathrm{~K}^{-1}\right)$, respectively.

The circular dichroism analysis was carried out using $3.0 \mathrm{~mL}$ of an HSA solution $\left(1.00 \times 10^{-6} \mathrm{M}\right.$ in PBS $)$ in 
the absence and presence of $4 \mathbf{c}\left(1.32 \times 10^{-5} \mathrm{M}\right)$ in the $200-250 \mathrm{~nm}$ range, at $310 \mathrm{~K}$. The intensity of the signal from the circular dichroism spectra was expressed as mean residue ellipticity (MRE), defined according to equation $7: 47$

$\mathrm{MRE}=\frac{\theta}{\left(10 \mathrm{nlC}_{\mathrm{P}}\right)}$

where $\theta, \mathrm{n}, 1$ and $\mathrm{C}_{\mathrm{p}}$ are the observed circular dichroism (in milli-degrees), number of amino acid residues (585 for HSA $),{ }^{39}$ optical pathlength of the cell $(1.00 \mathrm{~cm})$ and molar concentration of HSA $\left(1.00 \times 10^{-6} \mathrm{M}\right)$, respectively.

To obtain quantitative information on the percentage of changes in the $\alpha$-helix content upon $\mathbf{4 c}$ binding, the results of mean residue ellipticity (MRE) at 208 and $222 \mathrm{~nm}$ were analyzed according to equations 8 and $9:{ }^{47}$

$$
\begin{aligned}
& \alpha-\operatorname{helix}(\%)=\frac{\left(-\mathrm{MRE}_{208}-4000\right)}{(33000-4000)} 100 \\
& \alpha-\operatorname{helix}(\%)=\frac{\left(-\mathrm{MRE}_{222}-2340\right)}{30300} 100
\end{aligned}
$$

Time-resolved fluorescence measurements were performed on a model FL920 CD fluorimeter from Edinburgh Instruments (Edinburgh, UK), equipped with an electrically pumped laser (EPL, $\lambda_{\mathrm{exc}}=280 \pm 10 \mathrm{~nm}$; pulse of 850 ps with energy of $1.8 \mu \mathrm{W}$ per pulse; monitoring emission at $340 \mathrm{~nm}$ ). The time-resolved fluorescence decay of a $3.0 \mathrm{~mL}$ solution of HSA $\left(1.00 \times 10^{-5} \mathrm{M}\right.$, in PBS) was measured in the absence and presence of $\mathbf{4 c}$ $\left(1.32 \times 10^{-5} \mathrm{M}\right)$.

Synchronous fluorescence spectroscopy (SFS) and 3D fluorescence were performed in a model Xe900 fluorimeter from Edinburgh Instruments (Edinburgh, UK). Synchronous fluorescence spectra of a $3.0 \mathrm{~mL}$ solution of HSA $\left(1.00 \times 10^{-5} \mathrm{M}\right.$, in PBS) were measured without and in the presence of $\mathbf{4 c}$, in the $240-320 \mathrm{~nm}$ range by setting $\Delta \lambda=60$ and $15 \mathrm{~nm}$ for tryptophan and tyrosine residues, respectively. The ligand concentration was the same used in the steady state fluorescence studies at room temperature. 3D fluorescence spectra of HSA were recorded in the absence and presence of $\mathbf{4 c}$, using an excitation wavelength range of $200-340 \mathrm{~nm}$ and emission wavelength range of $210-460 \mathrm{~nm}$, at room temperature. 3D spectra were recorded for $3.0 \mathrm{~mL}$ of HSA solution $\left(1.00 \times 10^{-5} \mathrm{M}\right.$, at $\left.\mathrm{pH}=7.4\right)$ and for HSA:4c in the maximum concentration of quencher used in the steady state fluorescence measurements $\left(1.32 \times 10^{-5} \mathrm{M}\right)$.
Theoretical calculations

clog P calculations

The chemical structures of the samples under study $(\mathbf{2}, \mathbf{4 a}-\mathbf{4 d})$ were built and energy-minimized by density functional theory (DFT) calculations (B3LYP potential) with basis set 6-31G*, available in the Spartan' 14 program. ${ }^{48}$

\section{Molecular docking studies on HSA:4c}

The 4c structure was built and energy-minimized by DFT calculations, with B3LYP potential and basis set $6-31 G^{*}$, available in the Spartan' 14 program. ${ }^{48}$ The crystallographic structure of HSA was obtained in the Protein Data Bank (1N5U). ${ }^{39}$ The molecular docking studies were performed with GOLD 5.2 program (CCDC, Cambridge Crystallographic Data Centre). ${ }^{49}$

The hydrogen atoms were added to the albumin structure according to the data inferred by GOLD 5.2 program $^{49}$ on the ionization and tautomeric states. Docking interaction cavity in the protein was established with a $10 \AA$ radius from the Trp-214 residue. The number of genetic operations (crossover, migration, mutation) in each docking run used in the search procedure was set to 100,000 . The scoring function used was 'ChemPLP', which is the default function of the GOLD 5.2 program. ${ }^{49}$ For more details, see previous publications. ${ }^{44,47}$

\section{Results and Discussion}

\section{Chemistry}

The synthesis of the novel triazoles derivatives 4a-4d from natural piperine $\mathbf{1}$ was based on molecular hybridization strategy. ${ }^{33}$ The synthetic approach for the preparation of triazole derivatives has been described by Franklim et al..$^{24}$ This approach yielded the $N$-cyclohexyltriazole derivative $\mathbf{2}$ in five steps and a $47 \%$ overall yield from natural amide (Figure 1). Among the 13 triazoles synthesized by Franklim et al. ${ }^{24}$ derivative 2 exhibited the best activity profile against $T$. cruzi with low toxic effects against mammalian cells. For the preparation of the new $S$-alkylated triazoles $\mathbf{4 a - 4 d}$, the $N_{4}$-cyclohexyl triazole $\mathbf{2}$ was reacted with different alkyl iodides (methyl, isopropyl, $n$-butyl and benzyl) in refluxing basic ethanolic solution ${ }^{36}$ to afford the corresponding $S$-alkyl derivatives in yields ranging from 62 to $73 \%$ (Scheme 1).

Synthesis of the saturated triazole 5 (Scheme 2, entry 1) started with the catalytic reduction of the double bonds present in the piperic acid 9..$^{20,50}$ The resulting saturated acid $\mathbf{1 0}$ generated the saturated hydrazide $\mathbf{1 1}$ by treating the 

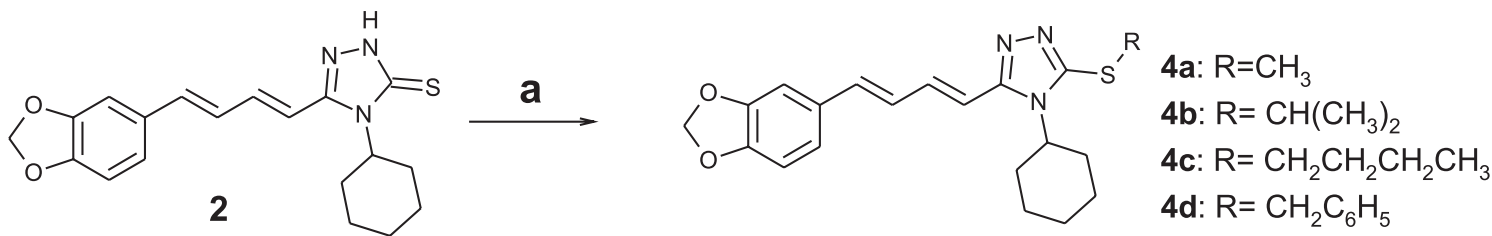

Scheme 1. Preparation of new $S$-alkylated $N_{4}$-cyclohexyl-1,2,4-triazole 4a-4d. Reaction conditions: (a) suitable alkyl iodide, KOH, ethanol, reflux $(62-73 \%$ yield).

former with oxalyl chloride. Next, there was a reaction with hydrazine monohydrate (Scheme 2, entry 1 ). The reaction of hydrazide 11 with cyclohexyl-isothiocyanate, followed by subsequent treatment of the respective carbothioamide intermediate with ethanolic $\mathrm{KOH}$ under reflux in an one-pot reaction, led to good yields of triazole 5 (Scheme 1, entry 1).

Synthesis of the lower vinyl homolog 6 (Scheme 2, entry 2), a derivative with a carbon-carbon double bond between the triazole group and the phenyl ring, started with a Knoevenagel reaction between 3,4-methylenedioxy benzaldehyde $\mathbf{1 2}$ and malonic acid, which generated the unsaturated acid 13. Preparation of triazole 6 from acid 13 passed through hydrazide $\mathbf{1 4}$ using the same methodology applied in the synthesis of triazole $\mathbf{5}$ (Schemes 2, entry 1). ${ }^{24}$

To obtain the triazole 7 (Scheme 2, entry 3 ) the saturated precursor 15 was prepared via the hydrogenation of the double bond present in the carboxylic acid $\mathbf{1 3}$ (Scheme 2, entry 3). Once the carboxylic acid $\mathbf{1 5}$ was prepared, the same methodology applied for the synthesis of the triazoles 5 and 6 was used, ${ }^{24}$ which generated a good yield of the triazole 7.

For the preparation of triazole $\mathbf{8}$ (Scheme 2, entry 4), the Knoevenagel reaction between 3-methoxy benzaldehyde 17 and malonic acid yielded the commercially available $\alpha, \beta$-unsaturated acid 17 (Scheme 1, entry 4), which was precursor of triazole $\mathbf{8}$ via the same reaction sequence described in the previous examples. ${ }^{24}$

All of the new triazoles prepared from natural piperine, e.g. $\mathbf{4 a - 4 d}$ and $\mathbf{5}$, as well as the new modified triazole analogues $\mathbf{6 , 7}$ and $\mathbf{8}$ were fully characterized and their respective spectrometric data $\left({ }^{1} \mathrm{H}\right.$ and ${ }^{13} \mathrm{C}$ NMR, MS, and HRMS) and melting points are described in the Experimental section. All spectra are shown in the Supplementary Information section.

\section{Biological assays}

The eight novel triazole derivatives prepared herein were evaluated in vitro against the replicative epi- and amastigote forms of $T$. cruzi (Y strain). The cytotoxicity evaluation was assessed on murine macrophages. First, the anti-epimastigote activity of the new derivatives $\mathbf{4 a - 4 d}$ and 5-8 were evaluated using triazole 2 and the commercial drug benznidazole as positive controls. The data are summarized in Table 1.

The novel synthesized triazole derivatives 4a-4d, 5-8 exhibited toxic effects against epimastigotes with $\mathrm{IC}_{50}$

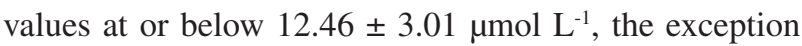
was compound $8\left(\mathrm{IC}_{50} \geq 79 \mu \mathrm{mol} \mathrm{L} \mathrm{L}^{-1}\right)$. Then, all of the compounds were evaluated for their cytotoxicity using trypan blue exclusion test in peritoneal macrophages from Balb/c mice. After $72 \mathrm{~h}$ of treatment, all concentrations tested of the triazole compounds $(0.5 ; 1.0 ; 2.5$ and $5.0 \mu \mathrm{g} \mathrm{mL}^{-1}$ ) showed no significant toxicity for the host cells; cellular viability ranged from $90-95 \%$ at the highest concentration assessed.

The $S$-alkyl-triazoles $\mathbf{4 a - 4 d}$ showed significant activity against epimastigote forms of $T$. cruzi with $\mathrm{IC}_{50}$ values ranging from $3.18 \pm 0.78$ to $7.52 \pm 1.65 \mu \mathrm{mol} \mathrm{L} \mathrm{L}^{-1}$. The introduction of the $S$-alkyl chain into the triazole ring contributed to the increased activity against epimastigotes compared with their precursor: the triazole 2 $\left(\mathrm{IC}_{50}=18.30 \pm 5.21 \mu \mathrm{mol} \mathrm{L}{ }^{-1}\right){ }^{24}$ These results highlight the lipophilicity of the sample, which may be a relevant parameter for the trypanocidal activity exhibited by this $S$-alkylated triazole series. To a better understanding of the relationship between lipophilicity and trypanocidal activity, the clogP values for $\mathbf{4 a - 4 d}$ triazoles were calculated (Table 2). The best trypanocidal profile was achieved by derivatives $\mathbf{4 b}, \mathbf{4 c}$ and $\mathbf{4 d}$, whose calculated clogP values were 6.60, 7.18 and 7.67, respectively. These results suggest an optimal lipophilicity range to the trypanocidal activity that may be related to the ability of these molecules to cross cell membranes. Similar correlations with different series of compounds have been observed by other authors such as Silva et al. ${ }^{51}$ These authors studied the tripanocidal activity of $1-N$ - and 3-N-alkyl-naphthoimidazoles.

Compounds 5-7, which had their butenodienylbenzodioxole moieties modified, exhibited toxic activity against epimastigotes (Table 1). The lack of trypanocidal effect exhibited by the methoxylated derivative $\mathbf{8}$ (Table 1) highlights the relevance of methylenedioxy substitution in the aromatic ring to the toxic activity against $T$. cruzi $^{20}$ Compound 5, which has a saturated spacer chain, showed an improved toxic activity against epimastigotes when compared to the unsaturated triazole 2 . This finding 
Entry 1<smiles>CC1(C)Oc2ccc(CCCCC(=O)O)cc2O1</smiles><smiles>S=c1[nH]nc(CCCCc2ccc3c(c2)OCO3)n1C1CCCCC1</smiles>

Reaction conditions: (a) $\mathrm{H}_{2}, \mathrm{Pd} / \mathrm{C}$, ethyl acetate, r.t., 30 min (89\% yield); (b) $(\mathrm{COCl})_{2}$, 30 min, r.t., then: $\mathrm{NH}_{2} \mathrm{NH}_{2} \cdot \mathrm{H}_{2} \mathrm{O}, \mathrm{CH}_{2} \mathrm{Cl}_{2}, 273 \mathrm{~K}$ to r.t. $(72 \%$ yield); (c) cyclohexyl isothiocyanate, ethanol, $\mathrm{MW}, 30 \mathrm{~min}$; (d) NaOH aq., $\mathrm{MW}, 30 \mathrm{~min}$, then $\mathrm{HCl}$ aq. until pH $3.0(72 \%$; $46 \%$ yield from acid 9).

Entry 2<smiles>O=Cc1ccc2c(c1)OCO2</smiles>

12<smiles>O=C(O)/C=C/c1ccc2c(c1)OCO2</smiles>

13 b<smiles>NNC(=O)/C=C/c1ccc2c(c1)OCO2</smiles>

14<smiles>S=c1[nH]nc(/C=C/c2ccc3c(c2)OCO3)n1C1CCCCC1</smiles>

Reaction conditions: (a) malonic acid, piperidine (catalytic), pyridine (reflux), then, $\mathrm{HCl}$ aq. $10 \%$ (75\% yield); (b), (c) and (d): same reaction conditions used in entry 1 (61\% yield for the three steps).

Entry 3

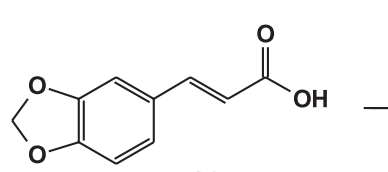

13<smiles>C[13CH]</smiles><smiles>CC1Oc2ccccc2O1</smiles>

$\mathrm{H}$<smiles>S=c1[nH]nc(CCc2ccc3c(c2)OCO3)n1C1CCCCC1</smiles>

15

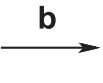

5<smiles>NNC(=O)CCc1ccc2c(c1)OCO2</smiles>

16

Reaction conditions: (a) $\mathrm{H}_{2}$, Pd/C, ethyl acetate, r.t., $30 \mathrm{~min}$ ( $89 \%$ yield); (b), (c) and (d): same reaction conditions used in entry 1 (57\% yield for the three steps).

Entry 4<smiles>CCC=O</smiles>

17<smiles>COc1cccc(/C=C/C(=O)O)c1</smiles>

18<smiles>COc1cccc(/C=C/C(=O)NN)c1</smiles>

19<smiles>COc1cccc(/C=C/c2n[nH]c(=S)n2C2CCCCC2)c1</smiles>

Reaction conditions: (a) malonic acid, piperidine (catal.), pyridine (reflux), then $\mathrm{HCl} 10 \%$ (70\% yield); (b), (c) and (d): same reaction conditions used in entry 1 ( $73 \%$ yield for the three steps).

Scheme 2. Preparation of novel modified $N_{4}$-cyclohexyl-1,2,4-triazole derivatives 5-8. 
Table 2. Calculated clogP values for the triazole-thione 2 and its $S$-alkylated derivatives $\mathbf{4 a - 4 d}$

\begin{tabular}{lc}
\hline Triazole & $\operatorname{clog} \mathrm{P}$ \\
\hline $\mathbf{2}$ & 5.08 \\
$\mathbf{4 a}$ & 5.94 \\
$\mathbf{4 b}$ & 6.60 \\
$\mathbf{4 c}$ & 7.18 \\
$\mathbf{4 d}$ & 7.67 \\
\hline
\end{tabular}

suggests that the flexibility of this chain may be an important structural feature for trypanocidal activity in this series of compounds. This observation contrasts with the results described by Otero et al.,$^{52}$ where the double bond saturation in a series of cinnamic acid esters resulted in a total lack of leishmanicial activity compared to its unsaturated precursor. Similarly, the saturated triazole 7 exhibited better activity than its unsaturated analogue $\mathbf{6}$ (Table 1). Compounds 6 and 7, containing two carbon atoms in the spacer chain, exhibited a slight increase in their trypanocidal activity when compared with their higher homologues with four carbon atoms (i.e., $\mathbf{2}$ and $\mathbf{4 c}$, respectively), which highlights the fact that chain size may have an impact on the toxic activity against the parasite.

All new derivatives exhibited significant toxic activity against amastigotes of T. cruzi, particularly the $S$-alkylated triazoles $\mathbf{4 b}, \mathbf{4 c}$ and $\mathbf{4 d}$, which showed trypanocidal activity comparable to the standard drug benznidazole. These triazoles had $\mathrm{IC}_{50}$ values of $3.95 \pm 1.41,4.15 \pm 0.92$ and $3.61 \pm 0.65 \mu \mathrm{mol} \mathrm{L}{ }^{-1}$, respectively. Among the derivatives that presented the highest toxic activity against $T$. cruzi, the triazole $\mathbf{4 c}$ was selected as a model to study the interactions with HSA, the main carrier protein in the human bloodstream, which is responsible for the distribution of several endogenous and exogenous molecules in the human $\operatorname{organism} .^{38}$

\section{Interaction between HSA and $\mathbf{4 c}$}

\section{Binding characterization for HSA:4c}

Steady state fluorescence spectroscopy can be used to monitor perturbations on HSA upon ligand binding. This interaction can lead to a decrease in the fluorescence quantum yield of the Trp-214 residue, which can result in changes in its position or orientation and consequently alter its exposure to a solvent. ${ }^{53,54}$ Figure 3 depicts the steady state fluorescence emission of HSA $\left(1.00 \times 10^{-5} \mathrm{M}\right)$ and its fluorescence quenching upon successive additions of $\mathbf{4 c}$, at $310 \mathrm{~K}$. It is worth noting that $\mathbf{4 c}$ exhibits some fluorescence emission in the 400-450 $\mathrm{nm}$ range, which does not affect the fluorescence behavior of the albumin. This potential antiparasitic drug was able to decrease the fluorescence emission of HSA $\left(\lambda_{\mathrm{em}}=340 \mathrm{~nm}\right)$, indicating that it may be located near to the Trp- 214 residue. ${ }^{40}$ Furthermore, the blue shift observed at the wavelength of the maximum emission of HSA upon ligand binding (from 340 to $316 \mathrm{~nm}$ ) is a clear evidence of an increase in the hydrophobicity around the Trp-214 residue..$^{53}$

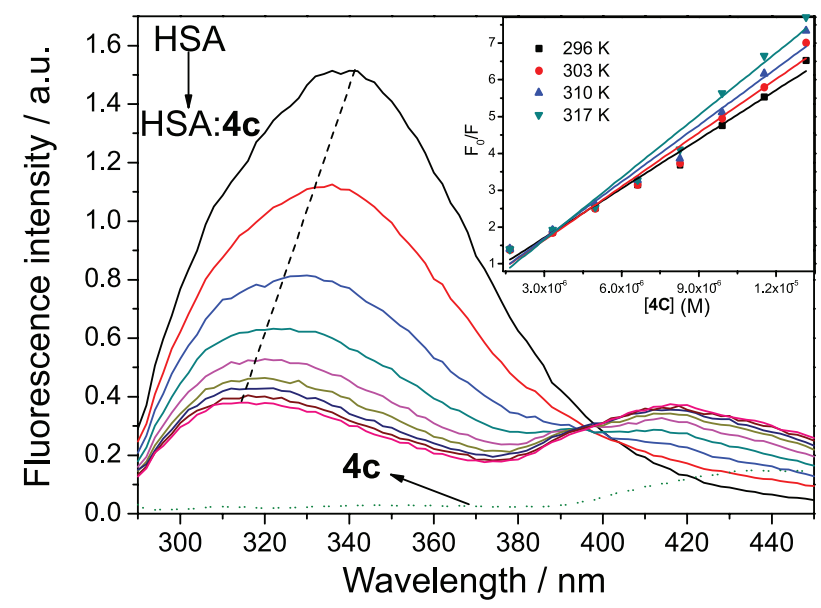

Figure 3. Steady state fluorescence emission of HSA and its quenching via successive additions of $\mathbf{4 c}$ at $\mathrm{pH}=7.4$ and $310 \mathrm{~K}$. Inset: SternVolmer plots for the interaction HSA:4c at 296, 303, 310 and $317 \mathrm{~K}$. $[\mathrm{HSA}]=1.00 \times 10^{-5} \mathrm{M}$ and $[\mathbf{4 c}]=0.17 ; 0.33 ; 0.50 ; 0.66 ; 0.83 ; 0.99 ; 1.15$; and $1.32 \times 10^{-5} \mathrm{M}$.

Fluorescence quenching corresponds to a decrease in fluorescence quantum yield induced by a variety of molecular interactions with the quencher molecule, such as excited-state reactions, molecular rearrangement, energy transfer, ground-state complex formation, and collisional quenching. However, in many instances the fluorophore can be quenched both by collisions and by complex formation with the same quencher. ${ }^{40}$

Table 3 lists the $\mathrm{K}_{\mathrm{Sv}}$ and $\mathrm{k}_{\mathrm{q}}$ values at 296, 303, 310, and $317 \mathrm{~K}$. The $\mathrm{k}_{\mathrm{q}}$ values are in the order of $10^{12} \mathrm{M}^{-1} \mathrm{~s}^{-1}$, higher than the maximum diffusion rate constant for water ( $\mathrm{k}_{\text {diff }}$ ca. $7.40 \times 10^{9} \mathrm{M}^{-1} \mathrm{~s}^{-1}$ at $298 \mathrm{~K}$, according to Smoluchowski-Stokes-Einstein theory at $298 \mathrm{~K}$ ), ${ }^{55}$ suggesting that a ground-state association can occur between HSA and $\mathbf{4 c}$, which is characteristic of a static mechanism. ${ }^{41}$ On the other hand, upward-trending curves in the Stern-Volmer plot at high ligand concentration can be observed (inset in the Figure 3). In addition, the $\mathrm{K}_{\mathrm{SV}}$ values increase with increasing temperature (Table 3 ), suggesting that the Trp-214 fluorescence can be quenched both by collision and by complex formation with the same quencher. ${ }^{40}$

To further confirm the presence of both fluorescence quenching mechanisms, static and dynamic, or the prevalence of only a static mechanism on the HSA:4c interaction, time 
Table 3. Binding constant values and thermodynamic parameters $\left(\mathrm{K}_{\mathrm{SV}}, \mathrm{k}_{\mathrm{q}}, \mathrm{n}, \mathrm{K}_{\mathrm{a}}, \Delta \mathrm{H}^{\circ}, \Delta \mathrm{S}^{\circ}\right.$ and $\left.\Delta \mathrm{G}^{\circ}\right)$ for the interaction between $\mathrm{HSA} \mathbf{4} \mathbf{c}$ at $296,303,310$ and $317 \mathrm{~K}$

\begin{tabular}{lccccccc}
\hline $\mathrm{T} / \mathrm{K}$ & $\mathrm{K}_{\mathrm{SV}} \times 10^{5} / \mathrm{M}^{-1}$ & $\mathrm{k}_{\mathrm{q}} \times 10^{13} /\left(\mathrm{M}^{-1} \mathrm{~s}^{-1}\right)$ & $\mathrm{n}$ & $\mathrm{K}_{\mathrm{a}} \times 10^{5} / \mathrm{M}^{-1}$ & $\Delta \mathrm{H}^{\circ} /\left(\mathrm{kJ} \mathrm{mol}^{-1}\right)$ & $\Delta \mathrm{S}^{\circ} /\left(\mathrm{kJ} \mathrm{mol}^{-1} \mathrm{~K}^{-1}\right)$ & $\Delta \mathrm{G}^{\circ} /\left(\mathrm{kJ} \mathrm{mol}^{-1}\right)$ \\
\hline 296 & $4.46 \pm 0.22$ & 8.17 & $1.28 \pm 0.03$ & $1.66 \pm 0.26$ & $5.13 \pm 0.29$ & $0.117 \pm 0.001$ & -29.5 \\
303 & $4.86 \pm 0.31$ & 8.90 & $1.31 \pm 0.04$ & $1.73 \pm 0.26$ & $5.13 \pm 0.29$ & $0.117 \pm 0.001$ & -30.3 \\
310 & $5.13 \pm 0.33$ & 9.40 & $1.33 \pm 0.04$ & $1.83 \pm 0.26$ & $5.13 \pm 0.29$ & $0.117 \pm 0.001$ & -31.1 \\
317 & $5.64 \pm 0.36$ & 10.3 & $1.39 \pm 0.06$ & $1.90 \pm 0.26$ & $5.13 \pm 0.29$ & $0.117 \pm 0.001$ & -32.0 \\
\hline
\end{tabular}

$\mathrm{T}$ : temperature; $\mathrm{K}_{\mathrm{SV}}$ : Stern-Volmer quenching constant; $\mathrm{k}_{\mathrm{q}}$ : bimolecular quenching rate constant; $\mathrm{n}$ : number of binding sites; $\mathrm{K}_{\mathrm{a}}$ : modified Stern-Volmer constant; $\Delta \mathrm{H}^{\circ}$ : enthalpy; $\Delta \mathrm{S}^{\circ}$ : entropy; $\Delta \mathrm{G}^{\circ}$ : Gibbs' free energy change.

resolved fluorescence measurements were carried out at $\mathrm{pH} 7.4$ for HSA in the absence and presence of the ligand in a higher concentration than that used in the steady state fluorescence quenching studies. Figure S26 and Table S1 (SI section) depict the time-resolved fluorescence decay and its parameters for HSA without and in the presence of $\mathbf{4 c}$. Free HSA showed two fluorescence lifetimes $\left(\tau_{1}=1.56 \pm 0.09 \mathrm{~ns}\right.$ and $\tau_{2}=5.46 \pm 0.08 \mathrm{~ns}$ ), with the longest lifetime showing the greatest contribution to the decay: $22.3 \%$ for $\tau_{1}$ and $77.7 \%$ for $\tau_{2}$. These results are in agreement with those in the literature. ${ }^{54}$ The addition of $\mathbf{4} \mathbf{c}$ to the HSA solution in PBS changes the albumin fluorescence lifetime inside the experimental error, e.g. $\tau_{2}$ showed a slight decrease to $5.39 \pm 0.10 \mathrm{~ns}$ for HSA:4c at the ligand concentration of $1.32 \times 10^{-5} \mathrm{M}$. The time-resolved fluorescence measurements suggested that only a static process was functioning as the main fluorescence quenching mechanism. This mechanism involved the formation of a ground-state complex. ${ }^{56}$ The natural product piperine (1) exhibited the same behavior when associated with HSA. ${ }^{45,57}$

Based on double logarithmic analysis for HSA:4c, the calculated number of binding sites (n) is approximately 1.00 at 296, 303, 310 and $317 \mathrm{~K}$ (Figure S27 and Table 3, SI section), indicating the existence of just one main binding site in the serum albumin structure for $\mathbf{4 c} .^{56}$ Since $\mathrm{n}$ ca. 1.00 , the binding constant parameter can be calculated according to the modified Stern-Volmer analysis (Figure S28, SI section). Table 3 lists the $\mathrm{K}_{\mathrm{a}}$ values for the interaction HSA:4c; these values are on the order of $10^{5} \mathrm{M}^{-1}$, the same order of magnitude noted for HSA:piperine..$^{45}$ This findings indicates that $\mathbf{4 c}$ can interact strongly with serum albumin. ${ }^{57,58} \mathrm{In}$ addition, the slight increase in the $\mathrm{K}_{\mathrm{a}}$ values with increasing temperature suggests that at body temperature $(310 \mathrm{~K})$, the antiparasitic triazole $\mathbf{4 c}$ presents better binding ability than at lower temperatures. ${ }^{57}$

The non-covalent interaction forces between xenobiotics and biomolecules may include hydrogen bonding, electrostatic forces, van der Waals forces and hydrophobic interactions. The sign and magnitude of the thermodynamic parameters such as enthalpy change $\left(\Delta \mathrm{H}^{\circ}\right)$ and entropy change $\left(\Delta \mathrm{S}^{\circ}\right)$ are important for the study of the interaction forces. ${ }^{58}$ The thermodynamic parameters associated with the interaction between HSA and $\mathbf{4 c}$ were calculated according to the van't Hoff (Figure S29, SI section) and Gibbs' free energy analysis.

The negative $\Delta \mathrm{G}^{\circ}$ values for the interaction HSA:4c are consistent with the spontaneity of the binding process in all temperatures under study (Table 3).$^{56}$ The calculated $\Delta \mathrm{H}^{\circ}$ and $\Delta \mathrm{S}^{\circ}$ values are positive, indicating that only the entropy change value can contribute to $\Delta \mathrm{G}^{\circ}<0$, suggesting that the association is entropically driven. In other words, the unfavorable positive enthalpy change $\left(\Delta \mathrm{H}^{\circ}=5.13 \pm 0.29 \mathrm{~kJ} \mathrm{~mol}^{-1}\right)$ is compensated by the positive entropy change $\left(\Delta \mathrm{S}^{\circ}=0.117 \pm 0.001 \mathrm{~kJ} \mathrm{~mol}^{-1} \mathrm{~K}^{-1}\right)$, suggesting that the binding of $4 \mathbf{c}$ to HSA may be governed by desolvation and/or hydrophobic factors..$^{59}$ In addition, according to the Ross and Subramanian ${ }^{60}$ theory, hydrogen bonding can also be considered as the main binding force due to $\Delta \mathrm{H}^{\circ}>0$.

\section{Investigation of HSA conformational changes}

The conformational change of the HSA structure induced by $\mathbf{4} \mathbf{c}$ binding was studied using circular dichroism spectroscopy. Serum albumin exhibits two negative signals at $208\left(\pi-\pi^{*}\right.$ transition $)$ and $222 \mathrm{~nm}\left(\mathrm{n}-\pi^{*}\right.$ transition $)$, which are due to the amide forming groups of the peptide bonds. ${ }^{61}$ Figure S30 (SI section) depicts the circular dichroism spectra for HSA in the absence and presence of $\mathbf{4 c}$ at $\mathrm{pH}=7.4$ and $310 \mathrm{~K}$.

The circular dichroism signal for HSA decreases with the addition of $\mathbf{4 c}$ (Figure S30, SI section), indicating changes in the protein structure upon ligand binding. ${ }^{41}$ However, the quantitative $\alpha$-helical percentage content for HSA with and without $\mathbf{4 c}$ did not change significantly, varying from $63.4-55.9 \%$ at $208 \mathrm{~nm}$ and from 58.6-56.4\% at $222 \mathrm{~nm}$. These results indicate that the presence of $\mathbf{4 c}$ results in a moderate perturbation to the secondary structure of the albumin..$^{62,63}$

Synchronous fluorescence spectroscopy (SFS) is a sensitive technique for analyzing micro-environmental 
changes in a vicinity of a chromophore. This technique involves simultaneous scanning of excitation and emission monochromators of a fluorimeter, with a fixed wavelength difference $(\Delta \lambda)$ between them. In the case of HSA, when $\Delta \lambda=15$ and $60 \mathrm{~nm}$ the synchronous fluorescence spectra exhibits the spectral character of the tyrosine and tryptophan residues, respectively. ${ }^{64}$ These spectra are shown in Figure 4 without and in the presence of successive additions of $\mathbf{4 c}$ at room temperature $(\mathrm{pH}=7.4)$. At $\Delta \lambda=15 \mathrm{~nm}$, there is no significant change in the maximum fluorescence wavelength position upon increasing the ligand concentration, indicating that $\mathbf{4 c}$ binding does not exert any influence on the polarity around the tyrosine residue. ${ }^{63}$ On the other hand, at $\Delta \lambda=60 \mathrm{~nm}$, a slight blue shift from 277 to $273 \mathrm{~nm}$ was observed, suggesting that the presence of $\mathbf{4 c}$ can increase the hydrophobicity around the Trp-214 residue. ${ }^{65,66}$ This result is fully consistent with the steady state fluorescence results described above.

Recently, three-dimensional (3D) fluorescence spectroscopy has become a significant analytical technique for studying macromolecules, because it provides very detailed information about the conformational changes in proteins. This information may include a shift in excitation or fluorescence emission wavelength, as well as the appearance of a new peak or the disappearance of an already existing peak. ${ }^{67}$ To further confirm the conformational and microenvironmental changes observed for HSA from the circular dichroism and SFS results described above, 3D spectra were recorded for pure HSA and HSA:4c (Figure 5 and Table 4).

Peaks 'a' $\left(\lambda_{\mathrm{ex}}=\lambda_{\mathrm{em}}\right)$ and 'b' $\left(2 \lambda_{\mathrm{ex}}=\lambda_{\mathrm{em}}\right)$ are referred to Rayleigh and second order scattering peaks, respectively. ${ }^{58}$ Peak I $\left(\lambda_{\text {ex }}=280 \mathrm{~nm}\right)$ mainly represents the structural characteristics of the polypeptide backbone caused by a $\pi \rightarrow \pi^{*}$ transition of the amide group responsible for the peptide bond and reflects the conformational changes of the protein. Peak II $\left(\lambda_{\text {ex }}=225 \mathrm{~nm}\right)$ is related to the spectral behavior of Trp and Tyr residues caused by a $\pi \rightarrow \pi^{*}$ transition and reflects the polarity of the microenvironment. ${ }^{68}$

The presence of $4 \mathbf{c}\left(1.32 \times 10^{-5} \mathrm{M}\right)$ in the HSA solution led to a significant reduction in the fluorescence intensity of the latter, showing 42.5 and $42.2 \%$ quenching for peaks I and II, respectively. A decrease in the magnitude of the Stokes shift, from 330 to $320 \mathrm{~nm}$ for peak I and from 335 to $320 \mathrm{~nm}$ for peak II can also be observed. These changes in the $3 \mathrm{D}$ fluorescence spectrum of HSA when in the presence of $\mathbf{4 c}$ can fully confirm the structural and microenvironment perturbations upon drug binding. ${ }^{69}$ On the basis of comparing the $3 \mathrm{D}$ and SFS results, there is strong evidence that the perturbation on the microenvironment occurs mainly around the Trp residue.

\section{Competitive binding studies and theoretical analysis on HSA:4c}

The HSA structure possesses different binding sites with distinct specificities, with domains I (Sudlow's site I, in subdomain IIA, warfarin binding site) and II (Sudlow's site II, in subdomain IIIA, ibuprofen binding site) being considered the most important; however, the subdomain IB (digitoxin binding site) is also an important site due to its ability to interact with some ligands. ${ }^{39}$ To identify the main binding site in the HSA structure responsible for the interaction with $\mathbf{4 c}$, competitive binding studies were performed with the site markers warfarin, ibuprofen and digitoxin (Figure S31, SI section). For the interaction HSA:4c, without the presence of site markers, a $K_{a}$ value of $(1.83 \pm 0.26) \times 10^{5} \mathrm{M}^{-1}$ at $310 \mathrm{~K}$ was obtained (Table 3 ), while $\mathrm{K}_{\mathrm{a}}$ values of $(1.52 \pm 0.26) \times 10^{5},(1.79 \pm 0.26) \times 10^{5}$ and $(1.81 \pm 0.26) \times 10^{5} \mathrm{M}^{-1}$ at $310 \mathrm{~K}$ were measured in the presence of warfarin, ibuprofen and digitoxin, respectively.
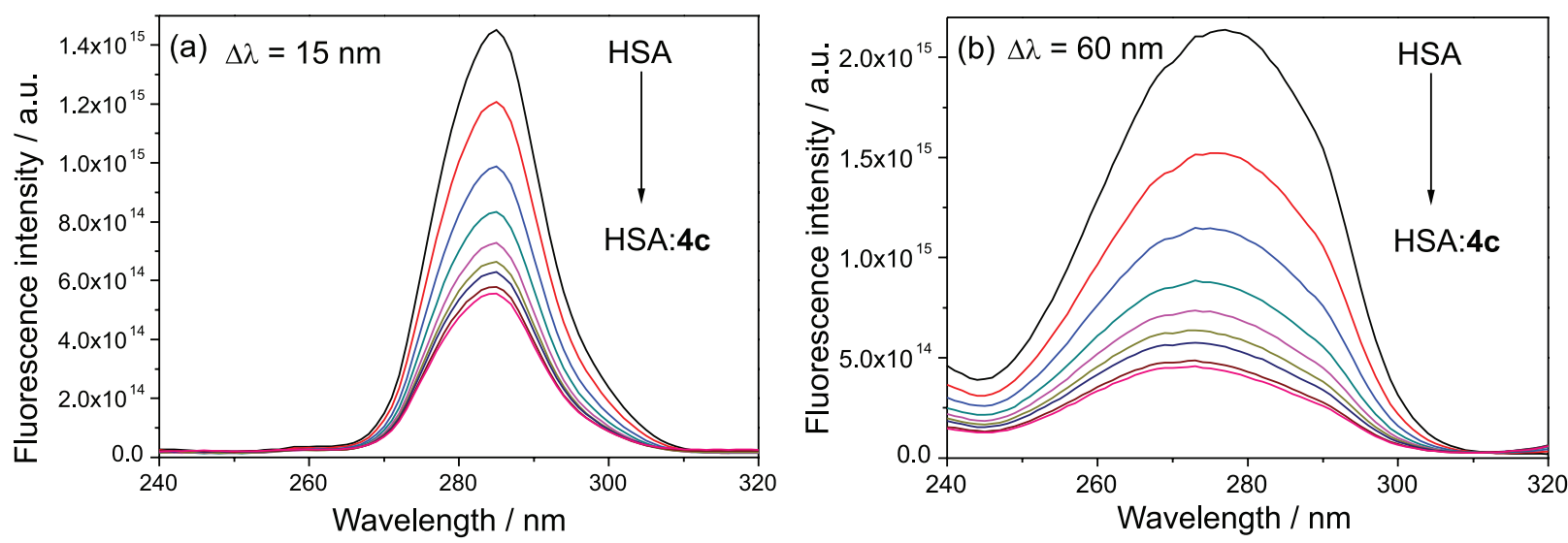

Figure 4. Synchronous fluorescence spectra of HSA with and without successive additions of $4 \mathbf{c}$ at (a) $\Delta \lambda=15 \mathrm{~nm}$ and (b) $\Delta \lambda=60 \mathrm{~nm}$. [HSA] $=1.00 \times 10^{-5} \mathrm{M}$ and $[\mathbf{4 c}]=0.17 ; 0.33 ; 0.50 ; 0.66 ; 0.83 ; 0.99 ; 1.15 ;$ and $1.32 \times 10^{-5} \mathrm{M}$. 

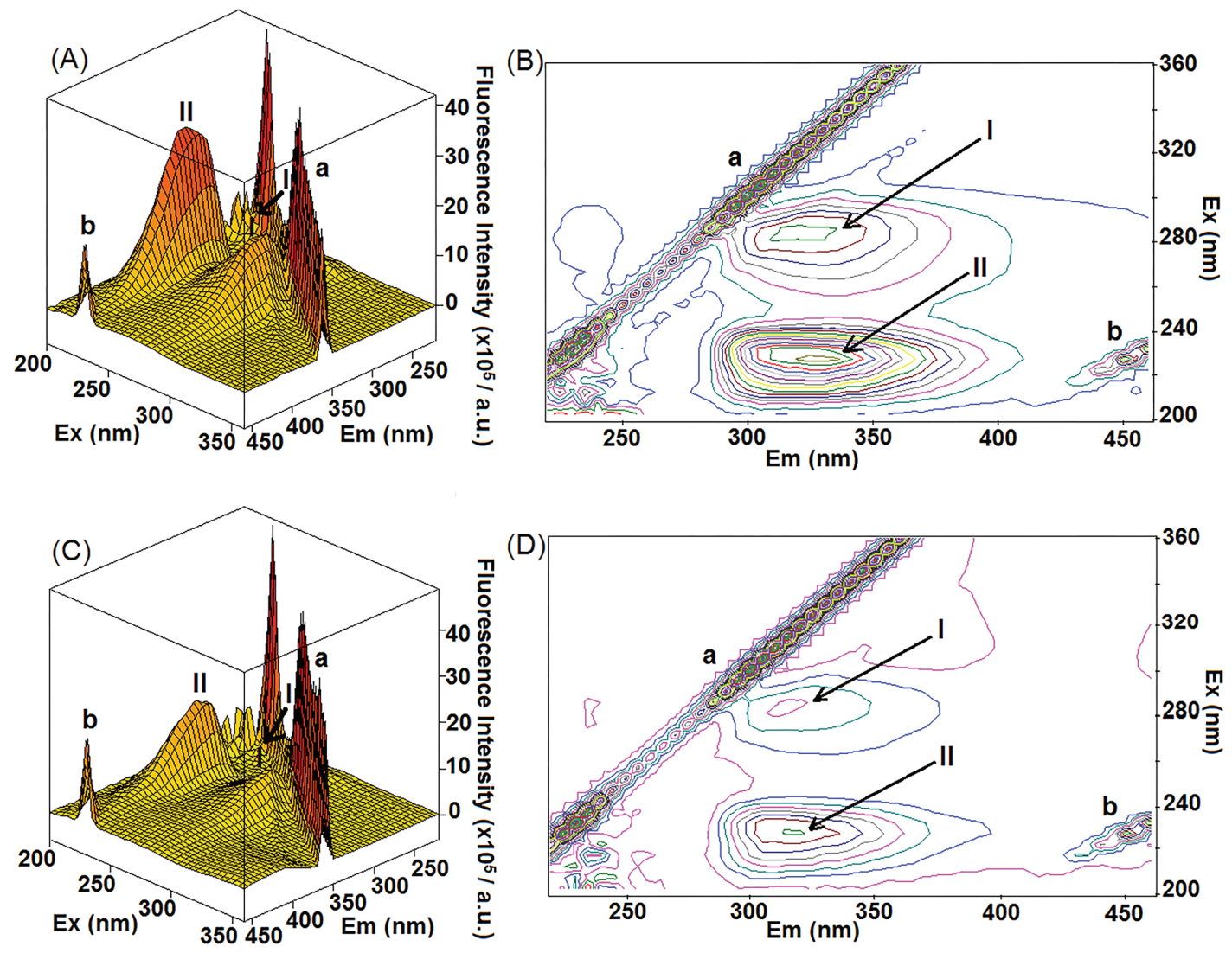

Figure 5. 3D fluorescence spectral projections and the corresponding contour maps for HSA (A and B) and HSA:4c (C and D), at pH 7.4 and r.t. $[\mathrm{HSA}]=1.00 \times 10^{-6} \mathrm{M}$ and $[\mathbf{4 c}]=1.32 \times 10^{-5} \mathrm{M}$.

Table 4. 3D fluorescence spectral characteristics for HSA and HSA:4c at $\mathrm{pH}=7.4$ and r.t.

\begin{tabular}{lccc}
\hline System & Peak & $\begin{array}{c}\text { Peak position }\left(\lambda_{\text {exc }} / \lambda_{\text {em }}\right) / \\
\mathrm{nm} / \mathrm{nm}\end{array}$ & Intensity $\times 10^{6} /$ a.u. \\
\hline \multirow{4}{*}{ HSA } & a & $220 / 220 \rightarrow 360 / 360$ & $2.55 \rightarrow 2.05$ \\
& b & $230 / 460$ & 1.56 \\
& I & $280 / 330$ & 1.27 \\
& II & $225 / 335$ & 2.89 \\
\hline \multirow{3}{*}{ HSA:4c } & a & $220 / 220 \rightarrow 360 / 360$ & $2.80 \rightarrow 2.20$ \\
& b & $230 / 460$ & 1.93 \\
& I & $280 / 320$ & 0.73 \\
& II & $225 / 320$ & 1.67 \\
\hline
\end{tabular}

These results clearly indicate that warfarin alters $\mathrm{K}_{\mathrm{a}}$ more significantly (17.0\%) than either ibuprofen $(2.19 \%)$ or digitoxin $(1.10 \%)$. Therefore, one can conclude that the main binding site for the association HSA:4c is the Sudlow's site I. ${ }^{62,70}$

To offer a molecular level explanation on the binding ability of $\mathbf{4 c}$ toward HSA, theoretical studies using molecular docking calculation were performed. Figure 6 shows the molecular docking results for the interaction between HSA and $\mathbf{4 c}$ inside Sudlow's site I, which suggest that the hydrogen atom from the guanidinium group of Arg-221 residue is a donor for hydrogen bonding with the sulfur group present in the ligand structure, within a distance of $2.80 \AA$. In addition, the peptide NH hydrogen of the Arg-484 residue is a donor group for hydrogen bonding with one of the oxygen atoms present on the benzodioxole ring of the ligand, within $2.40 \AA$. The molecular docking

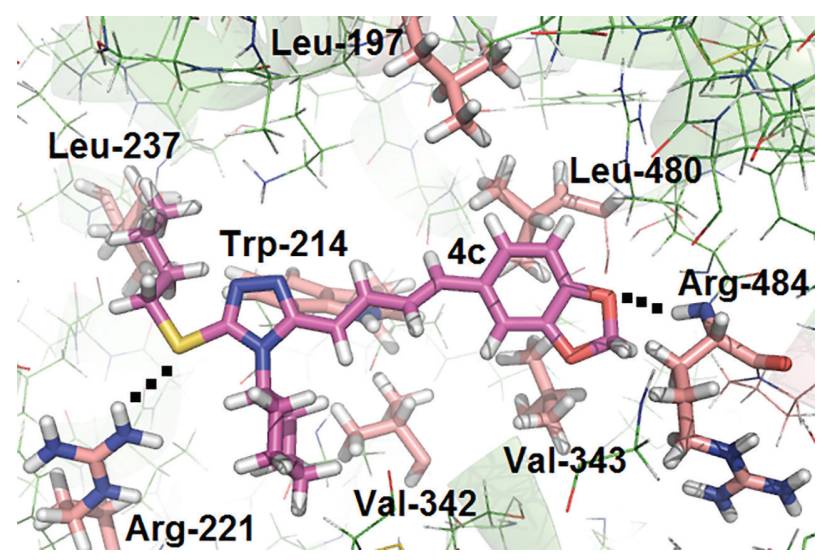

Figure 6. Best score pose for HSA:4c in Sudlow's site I (ChemPLP function). Selected amino acids residues and $\mathbf{4} \mathbf{c}$ are represented in beige and pink, respectively. Black dots represent the interaction via hydrogen bonding. Hydrogen: white; oxygen: red; nitrogen: dark blue and sulfur: yellow. 
results also suggest the presence of hydrophobic interactions between $4 \mathbf{c}$ and the Leu-197, Trp-214, Leu-237, Val-342, Val-343, and Leu-480 residues. These theoretical results are in full accordance with the intermolecular interactions suggested by the experimental thermodynamic parameters described above. ${ }^{59}$

\section{Conclusions}

Eight new triazole derivatives, that is $\mathbf{4 a - 4 d}$ and 5-8, were synthesized from natural piperine using a molecular hybridization strategy. All triazole derivatives were fully characterized by spectrometric analysis. Seven of the eight triazole derivatives $(\mathbf{4 a - 4 d , 5 , 6}$ and $\mathbf{7})$ displayed trypanocidal activities on proliferative forms of T. cruzi, and low level of toxicity on host cells (murine macrophages). Indeed, the $S$-alkylated triazole derivatives $\mathbf{4 b}, \mathbf{4 c}$ and $\mathbf{4 d}$ exhibited trypanocidal activity comparable to the standard drug benznidazole, with $\mathrm{IC}_{50}$ values of $3.95 \pm 1.41 ; 4.15 \pm 0.92$; and $3.61 \pm 0.65 \mu \mathrm{mol} \mathrm{L}-1$, respectively.

The quenching of HSA fluorescence after successive additions of $\mathbf{4} \mathbf{c}$ follows a static mechanism. Therefore, there must be a ground-state association between HSA and $\mathbf{4 c}$. The interaction between HSA and $\mathbf{4} \mathbf{c}$ is spontaneous, strong, entropy driven, able to change moderately the secondary structure of the albumin, and capable of perturbing the microenvironment around the Trp-214 residue. Hydrogen bonding and hydrophobic interactions are the main binding forces involved in the interaction HSA:4c. Sudlow's site I is the main binding site for $\mathbf{4 c}$ and molecular docking results suggest that the ligand can interact with Leu-197, Trp-214, Arg-221, Leu-237, Val-342, Val-343, Leu-480, and Arg-484 residues.

These results highlight the importance of abundant and accessible natural products as starting materials for the development of new and more effective antiparasitic drugs.

\section{Supplementary Information}

Supplementary information (spectroscopic characterization of the eight new triazole derivatives: ${ }^{1} \mathrm{H}$ NMR, ${ }^{13} \mathrm{C}$ NMR, and HRMS) and plots of the HSA binding studies (time-resolved decays, double logarithmic, modified Stern-Volmer, van't Hoff and CD spectra) are available free of charge at http://jbcs.sbq.org.br as PDF file.

\section{Acknowledgments}

This work was supported by the Brazilian research agencies: Conselho Nacional de Desenvolvimento
Científico e Tecnológico (CNPq); Coordenação de Aperfeiçoamento de Pessoal de Nível Superior, Brasil (CAPES), Finance Code 001; and Fundação de Amparo à Pesquisa do Estado do Rio de Janeiro (FAPERJ). Authors are grateful to Prof Dr Carlos M. R. Sant'Anna (Institute of Chemistry, UFRRJ) for the molecular docking facilities and Prof Dr Nanci Camara de Lucas Garden (Institute of Chemistry, UFRJ) for the time-resolved, synchronous and 3D fluorescence facilities.

\section{References}

1. https://apps.who.int/iris/bitstream/handle/10665/77472/ WHO_TRS_975_eng.pdf;jsessionid=AF567279B07956D 31B8128345FE4CDFD? sequence $=1$, accessed in February 2019.

2. Andrade, P.; Galo, O. A.; Carvalho, M. R.; Lopes, C. D.; Carneiro, Z. A.; Sesti-Costa, R.; de Melo, E. B.; Silva, J. S.; Carvalho, I.; Bioorg. Med. Chem. 2015, 23, 6815.

3. Booney, K. M.; Parasite 2014, 21, 11.

4. Lafferty, K. D.; Ecology 2009, 90, 888.

5. Coura, J. R.; de Castro, S. L.; Mem. Inst. Oswaldo Cruz 2002, $97,3$.

6. Castro, J. A.; de Mecca, M. M.; Bartel, L. C.; Hum. Exp. Toxicol. 2006, 25, 471 .

7. Ribeiro, I.; Sevcsik, A.-M.; Alves, F.; Diap, G.; Don, R.; Harhay, M. O.; Chang, S.; Pecoul, B.; PLoS Neglected Trop. Dis. 2009, 3, e484.

8. Sueth-Santiago, V.; Decote-Ricardo, D.; Morrot, A.; Freire-deLima, C. G.; Lima, M. E. F.; World J. Biol. Chem. 2017, 8, 57.

9. Uchiyama, N. J.; J. Health Sci. 2009, 55, 31.

10. Suto, Y.; Nakajima-Shimada, J.; Yamagiwa, N.; Onizuka, Y.; Iwasaki, G.; Bioorg. Med. Chem. Lett. 2015, 25, 2967.

11. dos Anjos, D. O.; Alves, E. S. S.; Gonçalves, V. T.; Fontes, S. S.; Nogueira, M. L.; Suarez-Fontes, A. M.; da Costa, J. B. N.; Rios-Santos, F.; Vannier-Santos, M. A.; Int. J. Parasitol.: Drugs Drug. Resist. 2016, 6, 207.

12. Izumi, E.; Ueda-Nakamura, T.; Veiga Jr., V. F.; Pinto, A. C.; Nakamura, C. V.; J. Med. Chem. 2012, 55, 2994.

13. Chataing, B.; Conception, J. L.; Lobatón, R.; Usubillaga, A.; Planta Med. 1998, 64, 31.

14. Sueth-Santiago, V.; Moraes, J. B.; Alves, E. S. S.; VannierSantos, M. A.; Freire-de-Lima, C. G.; Castro, R. N.; MendesSilva, G. P.; Del Cistia, C. N.; Magalhães, L. G.; Andricopulo, A. D.; Sant'Anna, C. M. R.; Decoté-Ricardo, D.; de Lima, M. E. F.; PLoS One 2016, 11, e0162926.

15. Semler, U.; Gross, G. G.; Phytochemistry 1988, 27, 1566.

16. Parmar, V. S.; Jain, S. C.; Bisht, K. S.; Jain, R.; Taneja, P.; Jha, A.; Tyagi, O. D.; Prasad, A. K.; Wengel, J.; Olsen, C. E.; Boll, P. M.; Phytochemistry 1997, 46, 597.

17. Srinivasan, K.; Crit. Rev. Food Sci. Nutr. 2007, 47, 735. 
18. Singh, I. P.; Choudhary, A.; Curr. Top. Med. Chem. 2015, 15, 1722 .

19. Gorgani, L.; Mohammadi, M.; Najafpour, G. D.; Nikzad, M.; Compr. Rev. Food Sci. Food Saf. 2017, 16, 124.

20. Ribeiro, T. S.; Freire-de-Lima, L.; Previato, J. O.; Previato, L. M.; Heise, N.; de Lima, M. E. F.; Bioorg. Med. Chem. Lett. 2004, 14, 3555.

21. Freire-de-Lima, L.; Ribeiro, T. S.; Rocha, G. M.; Brandão, B. A.; Romeiro, A.; Mendonça-Previato, L.; Previato, J. O.; de Lima, M. E. F.; de Carvalho, T. M.; Heise, N.; Parasitol. Res. 2008, 102, 1059.

22. Ferreira, W. S.; Freire-de-Lima, L.; Saraiva, V. B.; Alisson-Silva, F.; Mendonça-Previato, L.; Previato, J. O.; Echevarria, A.; Lima, M. E. F.; Bioorg. Med. Chem. 2008, 16, 2984.

23. Ferreira, C.; Soares, D. C.; Barreto-Junior, C. B.; Nascimento, M. T.; Freire-de-Lima, L.; Delorenzi, J. C.; de Lima, M. E. F.; Atella, G. C.; Folly, E.; Carvalho, T. M.; Saraiva, E. M.; Pintoda-Silva, L. H.; Phytochemistry 2011, 72, 2155.

24. Franklim, T. N.; Freire-de-Lima, L.; Diniz, J. N. S.; Previato, J. O.; Castro, R. N.; Mendonça-Previato, L.; de Lima, M. E. F.; Molecules 2013, 18, 6366.

25. Brener, Z.; Cançado, J. R.; Galvão, L. M. C.; Luz, Z. M. P.; Filardi, L. S.; Pereira, M. E. S.; Santos, L. M. T.; Cançado, C. B.; Mem. Inst. Oswaldo Cruz 1993, 88, 149.

26. Urbina, J. A.; Payares, G.; Molina, J.; Sanoja, C.; Liendo, A.; Lazardi, K.; Piras, M. M.; Piras, R.; Perez, N.; Wincker, P.; Ryley, J. F.; Science 1996, 273, 969.

27. Urbina, J. A.; Lira, R.; Visbal, G.; Bartrolí, J.; Antimicrob. Agents Chemother. 2000, 44, 2498.

28. Urbina, J. A.; Payares, G.; Sanoja, C.; Molina, J.; Lira, R.; Brener, Z.; Romanha, A. J.; Int. J. Antimicrob. Agents 2003, 21, 39.

29. Kharb, R.; Sharma, P.; Yar, M.; J. Enzyme Inhib. Med. Chem. 2011, 26, 1 .

30. Zhow, C.-H.; Wang, Y.; Curr. Med. Chem. 2012, 19, 239.

31. Papadopoulou, M. V.; Bloomer, W. D.; Rosenzweig, H. S.; O'Shea, I. P.; Wilkinson, S. R.; Kaiser, M.; Eur. J. Med. Chem. 2015, 103, 325.

32. Küçükgüzel, S. G.; Çıkla-Süzgün, P.; Eur. J. Med. Chem. 2015, 97, 830.

33. Pedrosa, M. O.; Cruz, R. M. D.; Viana, J. V.; Moura, R. O.; Ishiki, H. M.; Barbosa-Filho, J. M.; Diniz, M. F.; Scotti, M. T.; Scotti, L.; Bezerra-Mendonça, J. F.; Curr. Top. Med. Chem. 2017, 17, 1044.

34. Parker, J. E.; Warrilow, A. G. S.; Colls, H. J.; Martel, C. M.; Nes, W. D.; Fraaije, B. A.; Lucas, J. A.; Kelly, D. E.; Kelly, S. L.; J. Appl. Environ. Microbiol. 2010, 77, 1460.

35. Chen, C. K.; Leung, S. S. F.; Guilbert, C.; Jacobson, M. P.; Mckerrow, J. H.; Podust, L. M.; PLoS Neglected Trop. Dis. 2010, 4, e651.

36. El-Emam, A. A.; Al-Deeb, O. A.; Al-Omar, M.; Lehman, J.; Bioorg. Med. Chem. 2004, 12, 5107.
37. Zhang, Y.; Ho, A.; Yue, J.; Kong, L.; Zhou, Z.; Wu, X.; Yang, F.; Liang, H.; Eur. J. Med. Chem. 2014, 86, 449.

38. Naveenraj, S.; Anandan, S.; J. Photochem. Photobiol. C 2013, $14,53$.

39. Wardell, M.; Wang, Z.; Ho, J. X.; Robert, J.; Ruker, F.; Ruble, J.; Carter, D. C.; Biochem. Biophys. Res. Commun. 2002, 291, 913.

40. Chen, X.; Qian, K.; Chen, Q.; Eur. J. Med. Chem. 2015, 93, 492.

41. Wang, Y.; Wang, L.; Zhu, M.; Xue, J.; Hua, R.; Qing, X.; J. Lumin. 2019, 205, 210.

42. Contreras, V. T.; Morel, C. M.; Goldenberg, S.; Mol. Biochem. Parasitol. 1985, 14, 83.

43. IGOR Pro 2.03; WaveMetrics Inc., Lake Oswego, Oregon, USA, 2018.

44. Chaves, O. A.; Jesus, C. S. H.; Cruz, P. F.; Sant'Anna, C. M. R.; Brito, R. M. M.; Serpa, C.; Spectrochim. Acta, Part A 2016, 169, 175.

45. Yeggoni, D. P.; Rachamallu, A.; Kallubai, M.; Subramanyam, R.; J. Biomol. Struct. Dyn. 2015, 33, 1336.

46. Chilom, C. G.; Bacalum, M.; Stanescu, M. M.; Florescu, M.; Spectrochim. Acta, Part A 2018, 204, 648.

47. Chaves, O. A.; da Silva, V. A.; Sant'Anna, C. M. R.; Ferreira, A. B. B.; Ribeiro, T. A. N.; de Carvalho, M. G.; CesarinSobrinho, D.; Netto-Ferreira, J. C.; J. Mol. Struct. 2017, 1128, 606.

48. Spartan'14; Wavefunction Inc., Irvine, USA, 2014.

49. http://www.ccdc.cam.ac.uk/solutions/csd-discovery/ components/gold/, accessed in February 2019.

50. Venkatasamy, R.; Faas, L.; Young, A. R.; Raman, A.; Hider, R. C.; Bioorg. Med. Chem. 2004, 12, 1905.

51. Silva, A. M.; Araújo-Silva, L.; Bombaça, A. C. S.; MennaBarreto, R. F. S.; Rodrigues-Santos, C. E.; Ferreira, A. B. B.; Castro, S. L.; Med. Chem. Commun. 2017, 8, 952.

52. Otero, E.; Robledo, S. M.; Díaz, S.; Carda, M.; Muñoz, D.; Paños, J.; Vélez, I. D.; Cardona, W.; Med. Chem. Res. 2017, 23, 1378 .

53. Molina-Bolívar, J. A.; Ruiz, C. C.; Galisteo-González, F.; Donnell, M. M.-O.'; Parra, A.; J. Lumin. 2016, 178, 259.

54. Sun, H.; Liu, Y.; Li, M.; Han, S.; Yang, X.; Liu, R.; Luminescence 2016, 31, 335.

55. Montalti, M.; Credi, A.; Prodi, L.; Gandolfi, M. T.; Handbook of Photochemistry, $3^{\text {rd }}$ ed.; Taylor \& Francis: Boca Raton, USA, 2006.

56. Rudra, S.; Dasmandal, S.; Patra, C.; Mahapatra, A.; J. Mol. Struct. 2018, 1167, 107.

57. Suresh, D. V.; Mahesha, H. G.; Rao, A. G. A.; Srinivasan, K.; Biopolymers 2007, 86, 265.

58. Chaves, O. A.; Cesarin-Sobrinho, D.; Sant'Anna, C. M. R.; de Carvalho, M. G.; Suzart, L. R.; Catunda-Junior, F. E. A.; NettoFerreira, J. C.; Ferreira, A. B. B.; J. Photochem. Photobiol. A 2017, 336, 32. 
59. Rahman, Y.; Afrin, S.; Tabish, M.; Arch. Biochem. Biophys. 2018, 652, 27.

60. Ross, P. D.; Subramanian, S.; Biochemistry 1981, 20, 3096.

61. Chaves, O. A.; Teixeira, F. S. M.; Guimarães, H. A.; Braz-Filho, R.; Vieira, I. J. C.; Sant'Anna, C. M. R.; Netto-Ferreira, J. C.; Cesarin-Sobrinho, D.; Ferreira, A. B. B.; J. Braz. Chem. Soc. 2017, 28, 1229.

62. Chaves, O. A.; Soares, B. A.; Maciel, M. A. M.; Sant'Anna, C. M. R.; Netto-Ferreira, J. C.; Cesarin-Sobrinho, D.; Ferreira, A. B. B.; J. Braz. Chem. Soc. 2016, 27, 1858.

63. Guo, X.; Yao, J.; Liu, X.; Wang, H.; Zhang, L.; Xu, L.; Hao, A.; Spectrochim. Acta, Part A 2017, 198, 248.

64. Samari, F.; Shamsipur, M.; Hemmateenejad, B.; Khayamian, T.; Gharaghani, S.; Eur. J. Med. Chem. 2012, 54, 255.
65. Tian, J.; Chen, C.; Xue, M.; J. Spectrosc. 2011, 26, 195.

66. Li, X.; Chen, D.; Wang, G.; Lu, Y.; Eur. J. Med. Chem. 2013, $70,22$.

67. Cheng, Z.; Liu, R.; Jiang, X.; Spectrochim. Acta, Part A 2013, $115,92$.

68. Tang, B.; Huang, Y.; Ma, X.; Liao, X.; Wang, Q.; Xiong, X.; Li, H.; Food Chem. 2016, 212, 434.

69. Nasruddin, A. N.; Feroz, S. R.; Mukarram, A. K.; Mohamad, S. B.; Tayyab, S.; J. Lumin. 2016, 174, 77.

70. Poór, M.; Kunsági-Máté, S.; Bálint, M.; Hetényi, C.; Gerner, Z.; Lemli, B.; J. Photochem. Photobiol. B 2017, 170, 16.

Submitted: November 14, 2018

Published online: February 26, 2019 